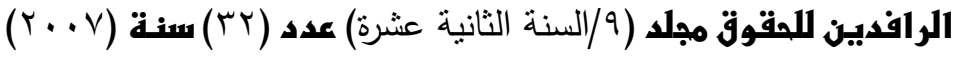

$$
\begin{aligned}
& {[r \cdot q u-|V| \text { ص }}
\end{aligned}
$$

$$
\text { قاعدة نسبية أثر العقد ومدى سريانها }
$$

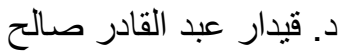

مدرس القانون الإداري

كلية القانون / جامعة المونل

إذا كان العقد الإداري لا يختلف في مفهومسه العـام عـن العقـد المـدني الـذي يبرهـه الأفراد فيما بينهم ، من حيث إن كلاً منهما يقوم على أساس توافر إرادتين بقصد القيام بالتزامات متقابلة ـ وعلى ذلك يلزم أن يتوافر في العقد الإداري كالعقـد المسني الأركـان الأساسية وهي الرضا - المحل والسبب إلا أنهما يختلفان مسن حيـث النظـام القـانوني الذي يخضع له كل منهما ، ومرجع هذا الاختلاف أن الإدارة وهي تبرم العقد باعتبارها سلطة عامة تتمتع بحقوق وامتيازات لا تتوافر للمتعاقد معها بهدف تحقيق ضسمان سـير مرافقها العامة بانتظام ـ وبالتالي فإنه في العقد الإداري تكـون كفتـا المتعاقدين متكافئسة حيث تغلب المصلحة العامة على المصلحة الفردية ، خلافـاً للعقـد المسني الـذي يجـب كقاعدة عامة أن تكون مصالح الطرفين متوازنة ومتساوية . وإذا كان من المسلم أن العقد المدني يخضع لقاعدة نسبية العقد في آثاره ، بمعنى أن

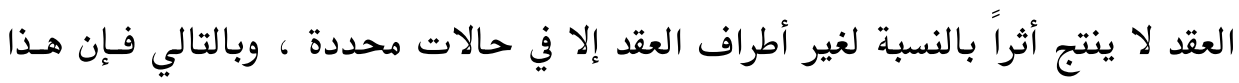
الأمر لا يثير إشكالية في العقد المدني ، إلا أن هذه الإشكالية تتأثر بالنسبة للعقد الإداري نظراً لخصوصيته واختلافه عن العقد المدني كما أشرنا سلفاً . إزاء ذلك كله تبرز لنا مشكلة مدى إمكانية تطبيق قاعدة أثر نسبية العقد على العقد الإداري على غرار العقد المدني من عدمهه . 


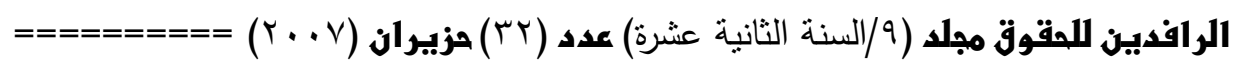

ومن هنا تبرز أهمية موضوع البحث في معالجـة هـذه المشكلة ولاسيما أن هنـاك اختلافاً بين فقهاء القانون الإداري تجاه تطبيق قاعدة نسبية العقد وأثرها ومدى سريانها تجاه العقد الإداري .

وبغية الوقوف على الحل الأمثل لهذه الإشكالية وللأهمية الكبرى لقاعدة نسبية أثر الدراه

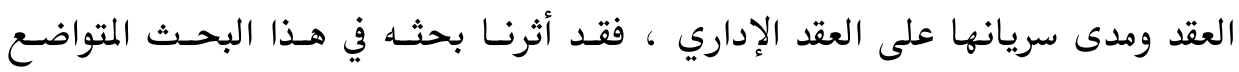

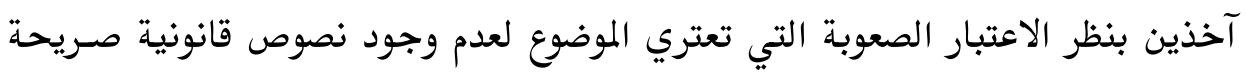

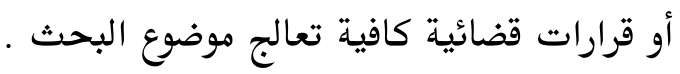

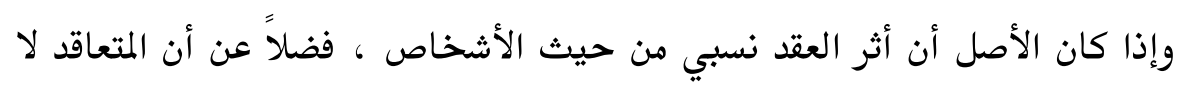

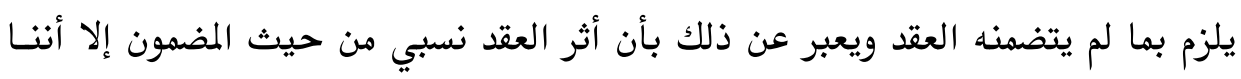

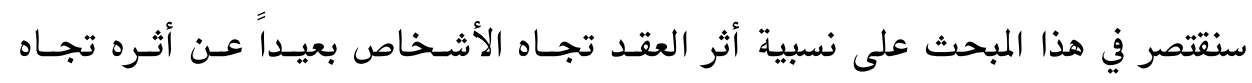

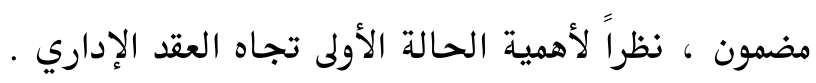

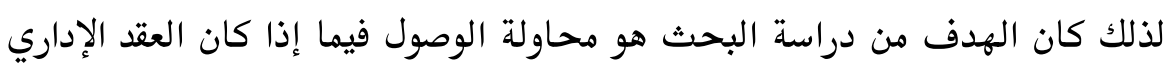

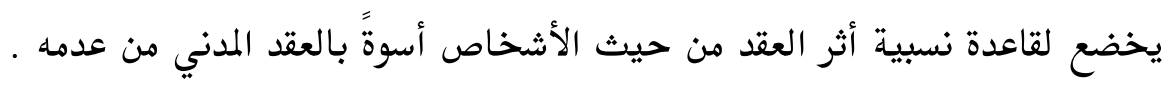

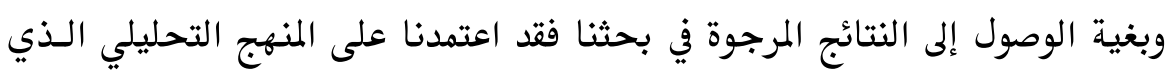

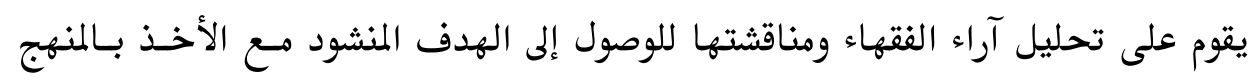

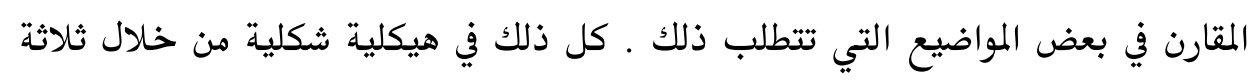
مباحث : المبحث الأول : ماهية قاعدة نسبية أثر العقد .

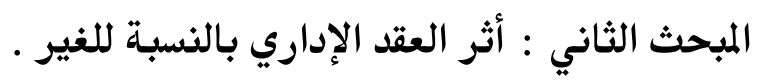
المبحث الثالث : مدى خضوع العقد الإداري لقاعدة نسبية أثر العقد . 


\section{المبحد: الؤو}

\section{ماهبة قاعدة نسبية أثر العقد}

يقتضي البحث في ماهية قاعدة نسبية أثر العقد تعريفه تمهيداً لبيان أثره بالنسبة

$$
\text { لكل من الخلف العام والخلف الخاص . }
$$

لذا سنتناول ماهية قاعدة نسبية أثر العقد في مطلبين . نسسلط الـضوء في الأول على لـى التعريف ، في حين نخصص المطلب الثاني لبيان أثر العقد بالنسبة لكل من الخلف العام والخلف الخاص . (- م.

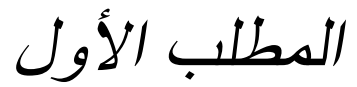

\section{التعربف بقاعدة نسبية أثر العقد}

يعني مبدأ نسبية أثر العقـد أن آثـار العقد تنـصرف إلى طرفيسه ، دون أن تتعـدى

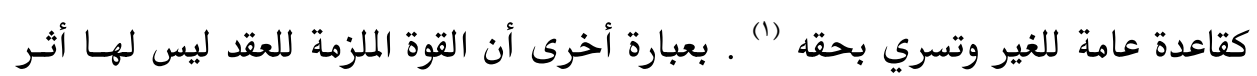

إلا على المتعاقدين ومن يكون في حكمهم (r)

(') د.حسن علي الذنون ، د.محمد سعيد الرحو ، الوجيز في نظرية الالتزام ، مصادر الالتزام

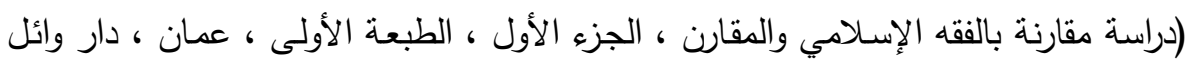

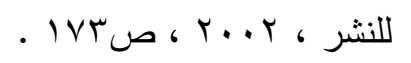

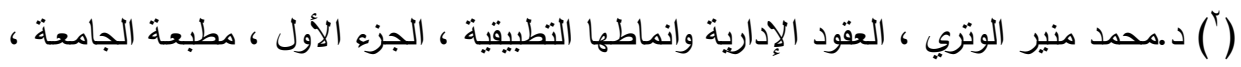

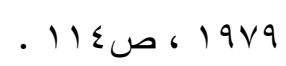

وقد كانت تللك القاعدة في شقيها قاعدة مطلقة في القانون الروماني ، بحيث لم يكن يضار

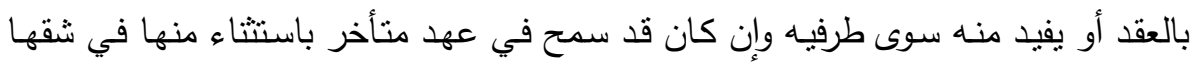

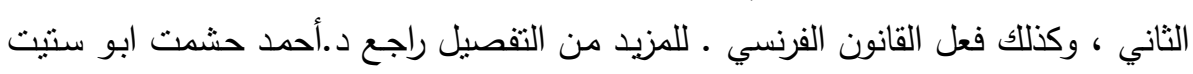

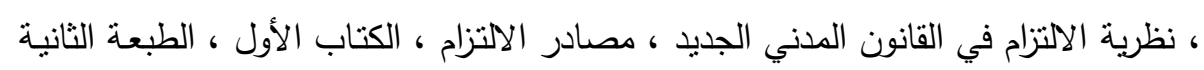

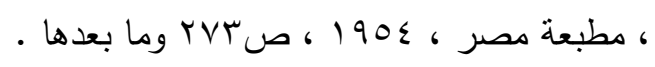




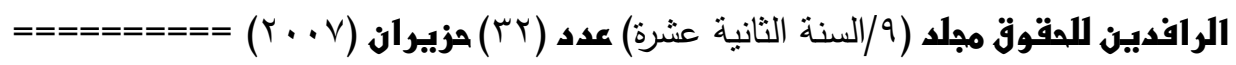

إذن يترتب على الأخذ بهذا المبدأ بأن أثر العقد يقتصر على طرفيه ، وبالتـالي فبإن

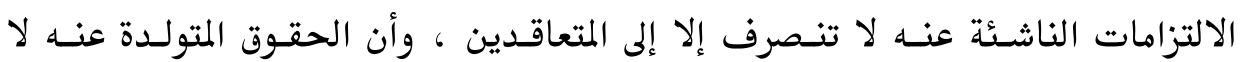

تنصرف كذلك إلا إلى طرفيه .

لكن إذا كان هذا المبدأ مطلقاً في شقه الأول ونعني بذلك الالتزامات ، فإنه يرد عليه

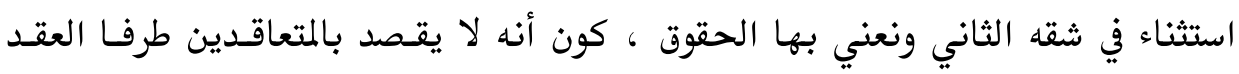

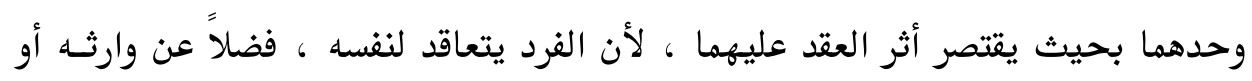

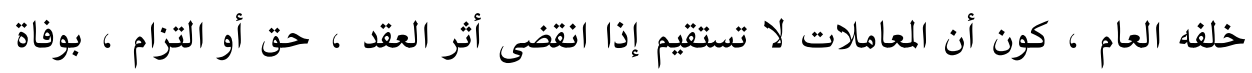

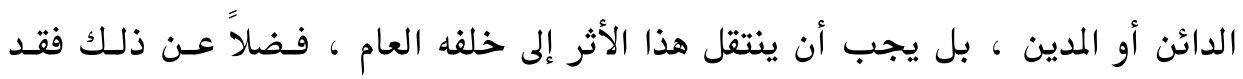

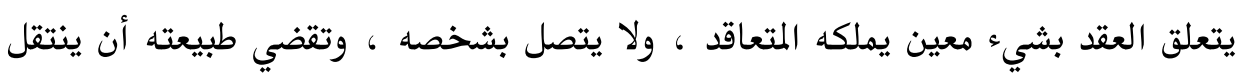

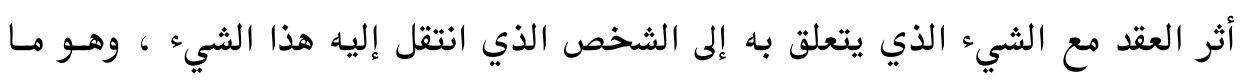

يعرف بالخلف الخاص (').

فأثر العقد ينصرف إلى المتعاقدين ومن يمثلانه في التعاقد ، والمتعاقد يمثل في تعاقده

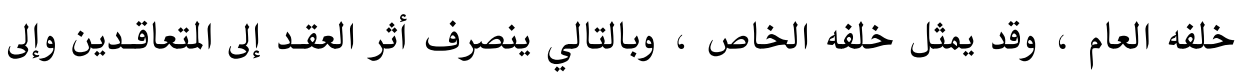

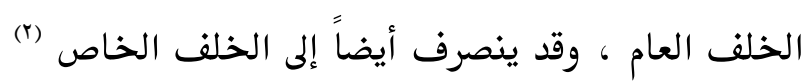

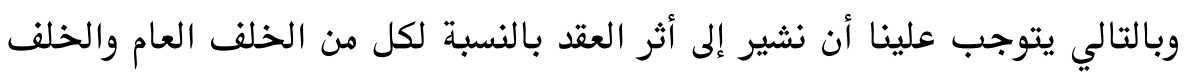
الخاص ، وهذا ما سيكون في المطلب القادم .

(') د.عبد العليم عبد المجيد مشرف ، حدود انصراف أثر العقد الإداري إلى الغير ، جامعة

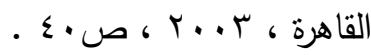

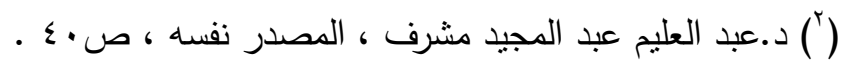




\section{المطلب الثانحي}

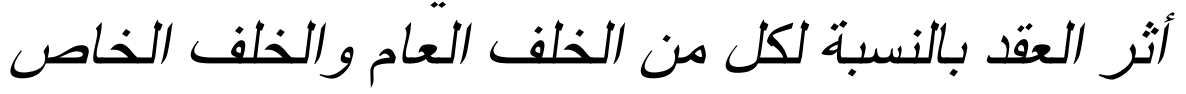

إذا كان أثر العقد ينصرف إلى كل من الخلف العام والخلف الخـاص ، كونهمـا لا

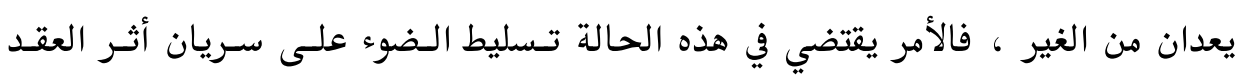
بالنسبة للخلف العام في الفرع الأول ، بينما نبين في الفرع الثاني أثره بالنسبة للخلـف

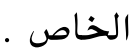

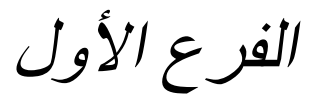 سربان أثر العقد بالنسبة للخلف العام}

الخلف العام هو من يخلف غيره في ذمته المالية كلهها أو في جـزء شـائع منهـا ، كالثلث والربع والنصف ، وهـذا يـشمل الـوارث والموصى لـه بجـزء شـائع كالثلث ، والخلف العام يخلف سـلفه بمقتـضى أحكـام المسيراث والوصية ، وبالتـالي يكـون مسن الطبيعي أن يتأثر بالعقود التي أبرمها سلفه (1)

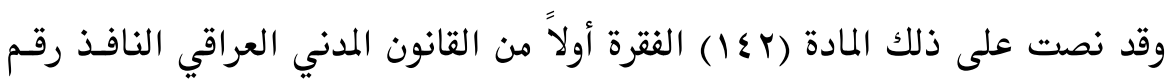
(•) لسنة 1901 بالقول ( يذصرف أثر العقد إلى المتعاقدين والخلف العـام دون إخـلال بالقواعد المتعلقة بالميراث ما لم يتبين من العقد أو من طبيعة التعامل أو من نص القانون أن هذا الأثر لا ينصرف إلى الخلف العام ) .

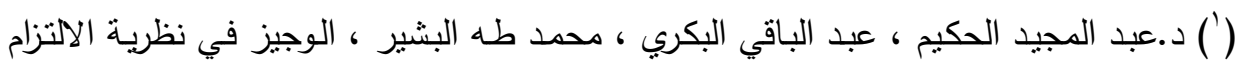

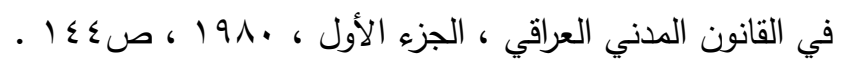

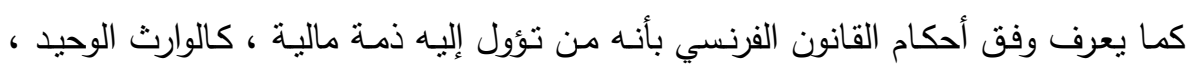

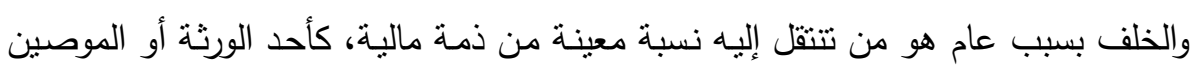

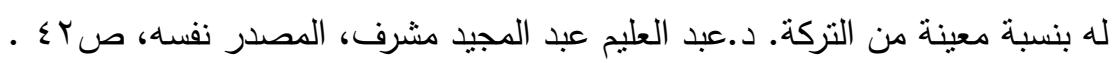




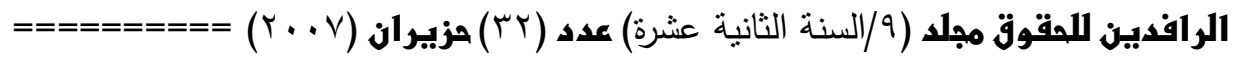

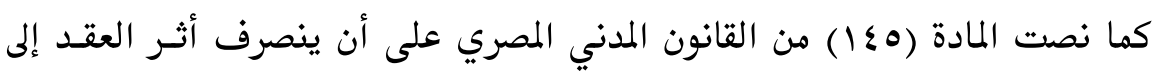

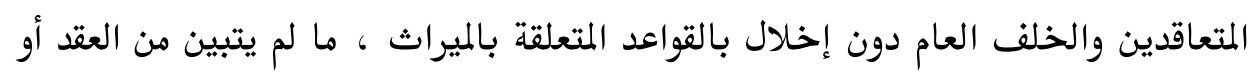

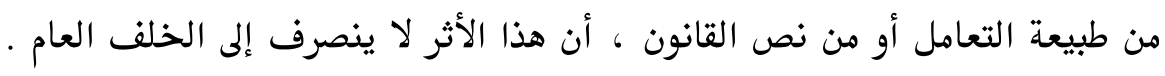

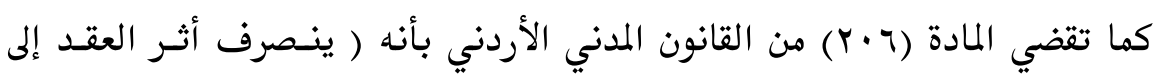

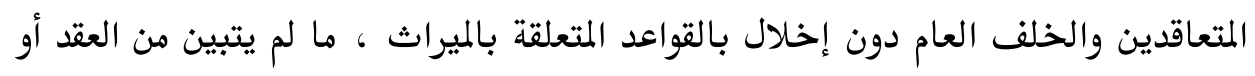
من طبيعة التعامل أو من نص القانون أن هذا الأثر لا ينصرف إلى الخلف العام ) .

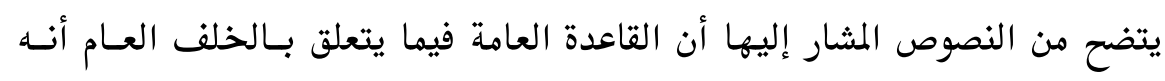

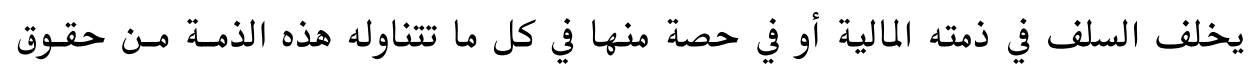

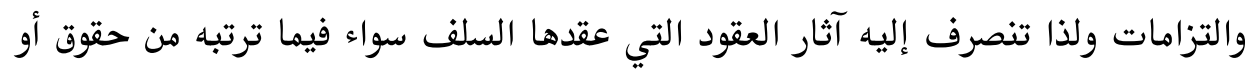

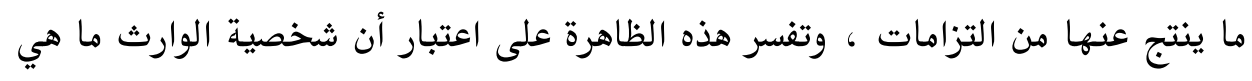

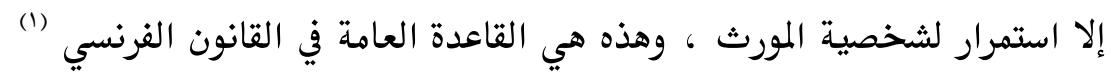

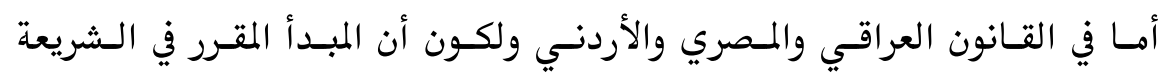

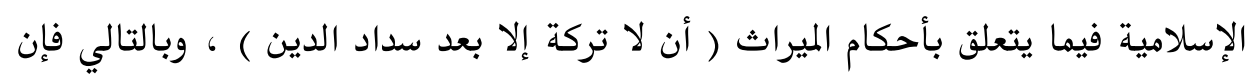

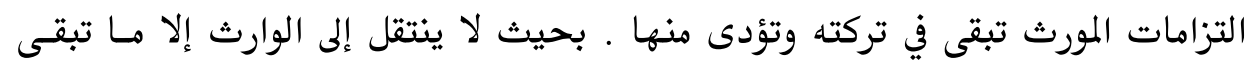

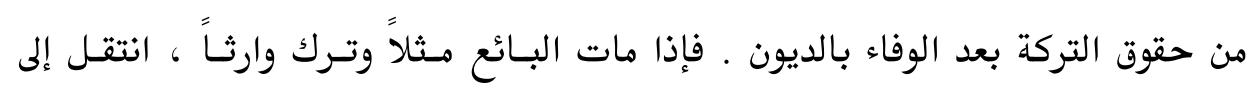

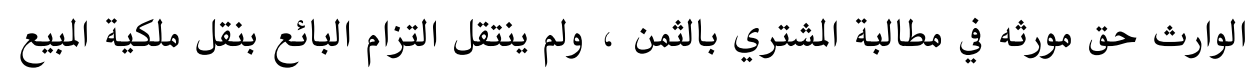

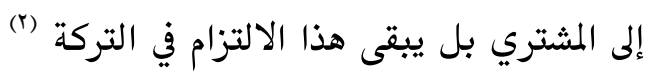

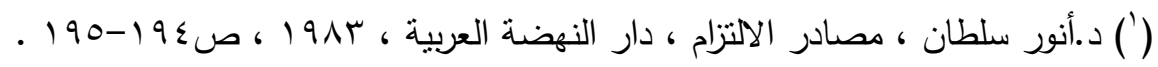

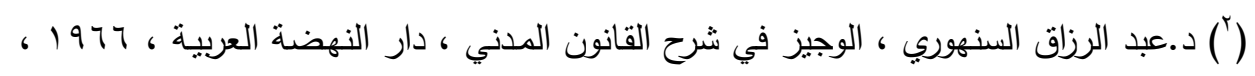

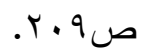




\section{الاستثناءات الواردة على القاعدة العامة :}

إذا ما فهمنا من النصوص التشريعية السالفة الذكر أن القاعدة العامة هي انصراف أثر العقد إلى الخلف العام ، إلا أن هذه القاعدة ليست مطلقة بل يرد عليها استثناء هام وهو عدم انصراف أثر العقد إلى الخلف العام في حالات معينـة أشـارت إليهـا النسوص التشريعية السالفة الذكر وهذه الحالات هي : أولًا : إذا اتفق المتعاقدان على ذلك ، وبالتالي يجوز مثلاً أن يتفق المتبايعان على مسنح

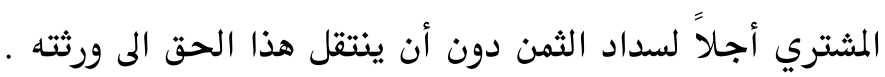

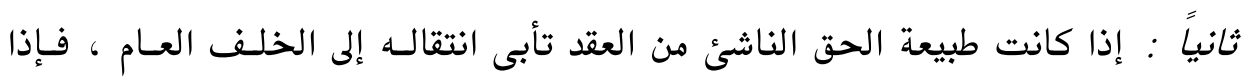
حصل شخص بموجب عقد على حق انتفاع فإن هـذا الحـق لا ينتقـل إلى وارث المنتفـع كون أن حق الانتفاع تقضي طبيعته أن ينتهي بموت صاحبه (1) ثالثًا : إذا كان هناك نص في القانون يقضي بعدم انتقال الحق إلى الوارث ، من ذلك ما

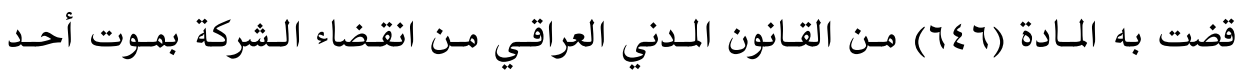

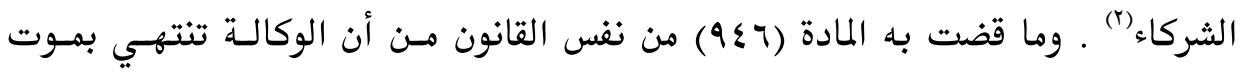
(الموكل

(') د.عبد الرزاق السنهوري ، الوسبط في شرح القانون المدني ، الجزء الأول ، نظرية الالتزام

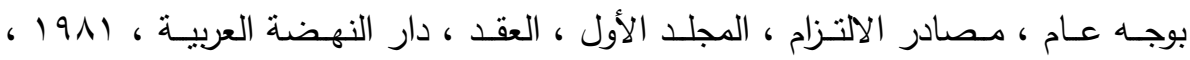
D VYT-VYO

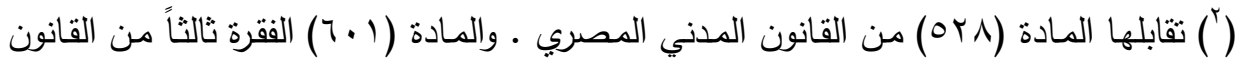

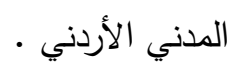

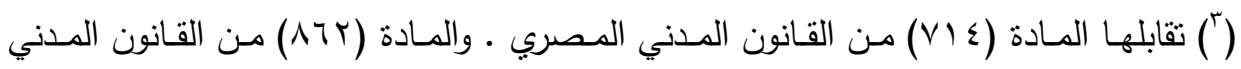

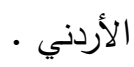




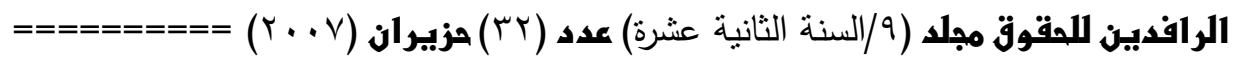

\section{الحالات التي يكون فيها الخلف من الغير :}

هناك فرض لا ينصرف فيه أثر التصرف إلى الوارث ، لأن الوارث يعتبر من الغير في

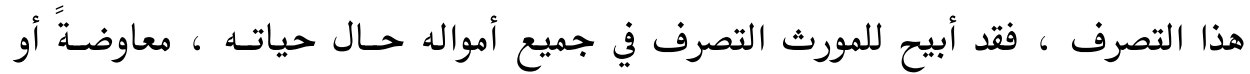

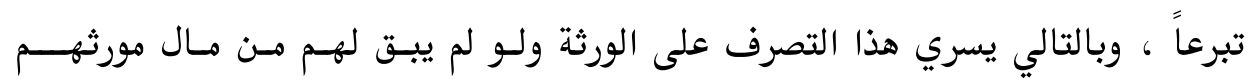

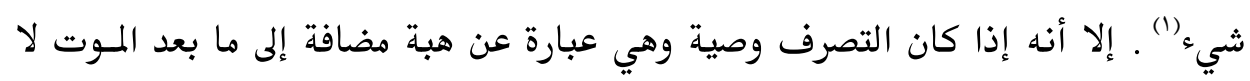

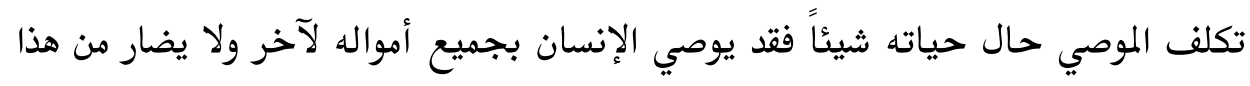

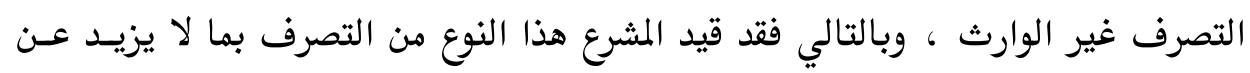
ثلث تركته ، فإن زاد عن هذا الحد اعتبر المشرع الخلف العام بالنسبة لهذا القدر الزايد

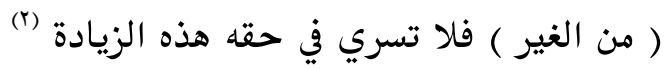

\section{الفر ع الثاني \\ سريان أثر العقد بالنسبة للخلف الخاص التي \\ أولاً : تعريف الخلف الخاص :}

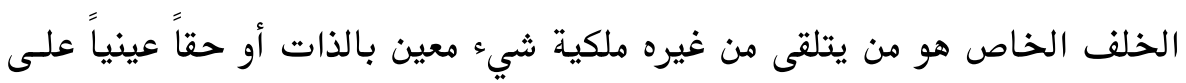

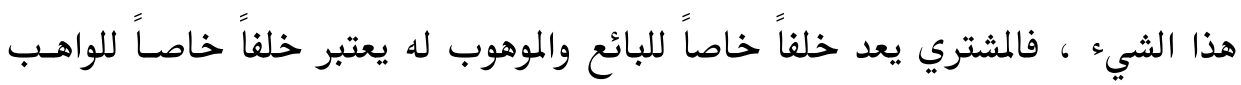

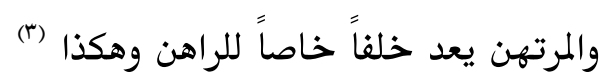

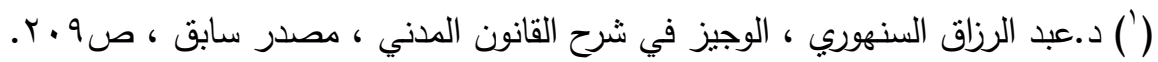

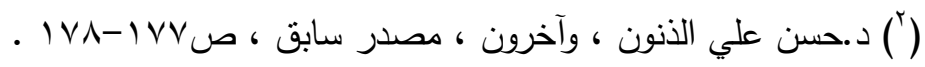

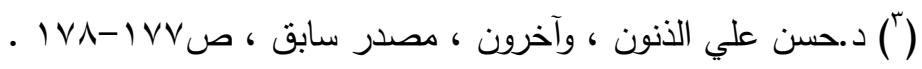


ثانياً : متى ينصرف أثر العقد إلى الخلف الخاص : تذص المادة (Y乏 I) الفقرة ثانياً من القانون المدني العراقي ( إذ أنشأ العقـد التزامـات

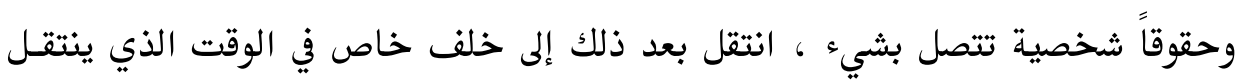
فيه الشيء إذا كانت من مستلزماته وكان الخلف الخاص يعلم بها وقت انتقـال الشيء إليه ) (1) . يتضح من هذا النص وجوب توافر الشروط الثلاثة الآتية : ا. أن يكون تصرف السلف مرتبطاً بالشيء أو بالحق الذي تلقاه الخلف . فإذا لم تكن للتصرف صلة ما بالـشيء أو بـالحق ، كمـا لـو كـان السلف قـد عقـد

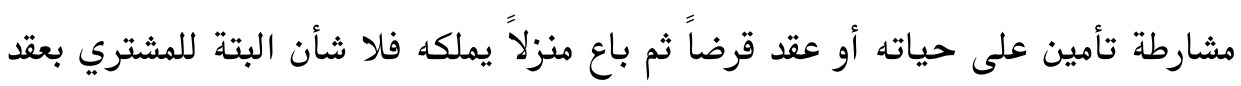
(r) التأمين أو القرض r. أن يكون الخلف الخاص قد علم بما ينتقل إليه من حقوق والتزامات . أما استطاعة العلم فلا تكفي في هذا المجال لدقة الموضوع · وأهمية هذا العلـم تظهـر

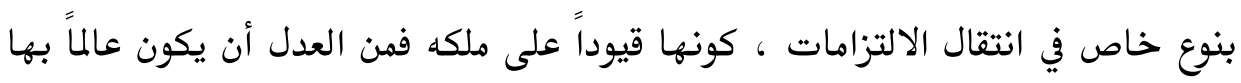
وقت انتقالها إليه

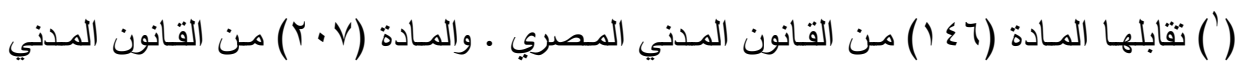
• الأردني

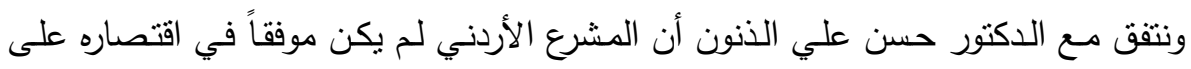

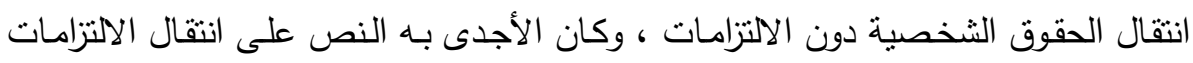

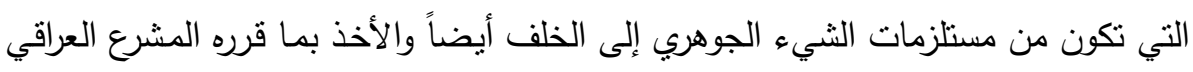

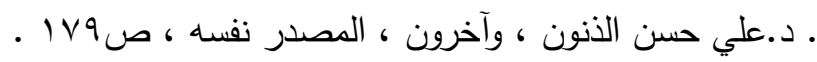

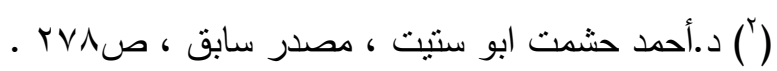

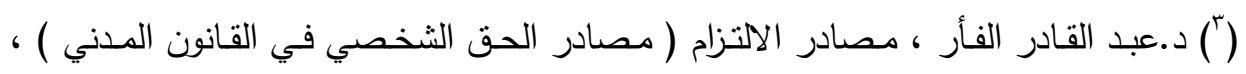

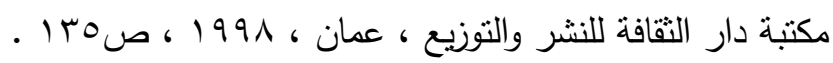




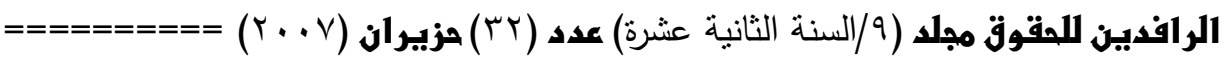

ويبرز التساؤل في هذا الصدد عن وضع الدائنين ، فهل يعتبر الـدئن خلفاً عامـاً أم

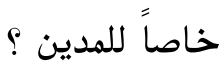

في الواقع نتفق مع الدكتور محمود جمال الدين زكي في الإجابة عن هذا التساؤل ،

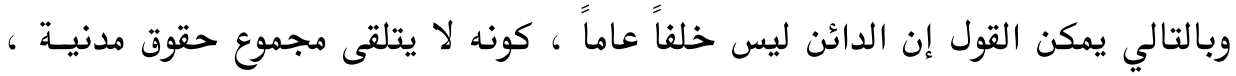

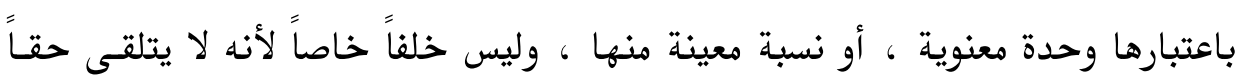

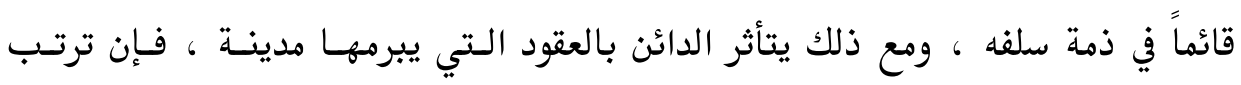
عليها زيادة أمواله ، قوى ضمانة ، وإن نجم عنها نقص أحواله ضعف ضمانه .

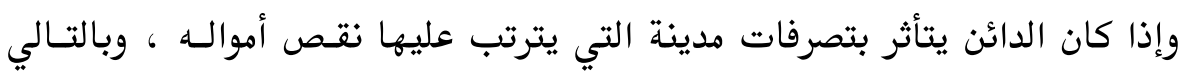

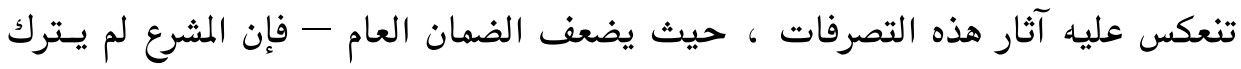

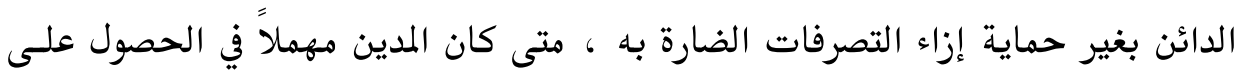

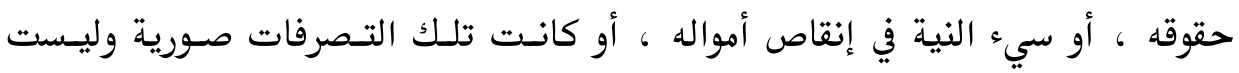
حقيقية ، حيث أجاز المشرع للدائن وبشروط معينـة استعمال الدعوى غـير المباشـرة المهرة والدعوى البوليصية ودعوى الصورية (1)

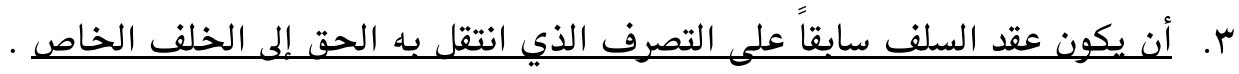

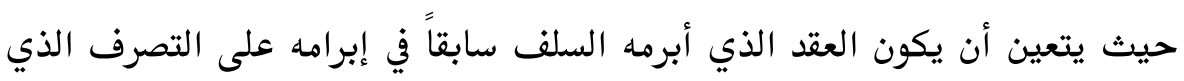

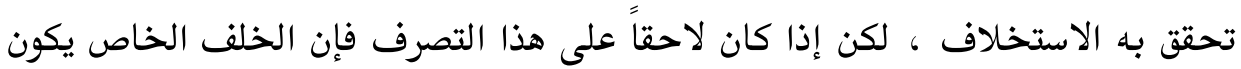

(') دمحمود جمال الدين زكي ، النظرية العامة للالتزام ، دار النشر وسنة النشر غير مذكورتين

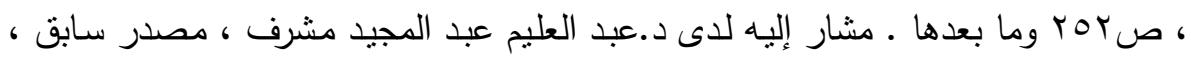
ص n 
أجنبياً تماماً عن هذا العقد ولا يذصرف أثره إليه ـ بمعنى يتعين لنكون بصدد أسبقية أن

يكون عقد السلف ثابت التاريخ (1)

ويثار تساؤل آخر في هذا الصدد يتعلق بالشرط الأول وهو متى يكون تصرف السلف

مرتبطاً بالشيء أو بالحق حتى يسري في حق الخلف الخاص له أو عليه ؟

في الواقع وضع معيار يستعان به في هذا الـشأن ، وهـو أن يكـون مـا ولـده تـصرف ترف

السسلف مسن حقـوق والتزامـات مسن مستتلزمات الـشيء أو الحـق الـذي تلقـاه الخلـف

الخاص(r)، وبالتالي تعتبر الحقوق من مستلزمات الشيء إذا كانت مكملة له بمعنسى أن

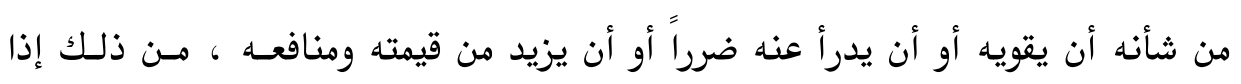

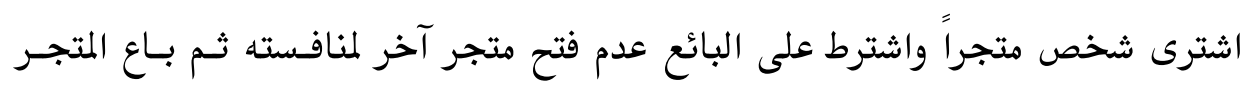

فإن حقه في عدم المنافسة ينتقل إلى المشتري الثاني ، لكون من شأن هذا الحق أن يسدرأ ضرراً عن المتجر وأن يزيد من قيمته ومنافعه .

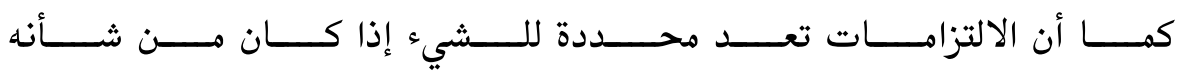

أن يلزم السلف باستعمال ملكه على نحو معين أو أن يغل يده عن استعمال بعض حقوق المالك ، من ذلك مثلاً إذا اشترى شخص قطعة أرض مقسمة إلى قطع لبناء الدور واشترط

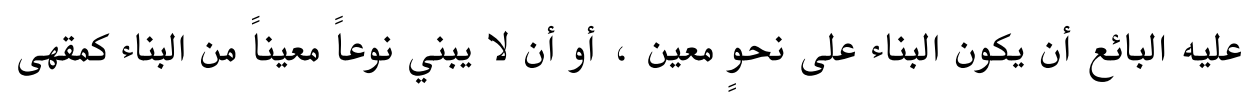
أو ملهى ، ثم باع المشتري قطعة الأرض ، فالتزامه بالبناء على النحـو المتفـق عليسه أو

بعدم بناء مقهى أو ملهمى ينتقل إلى المشتري (ب)

(') د.عبد الرزاق السنهوري ، الوسيط في شرح القانون المدني ، مصدر سابق ، صع ؟ V .

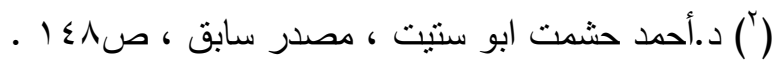

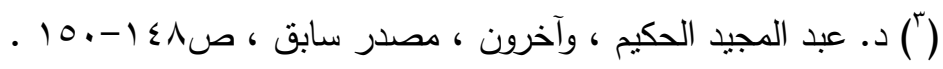




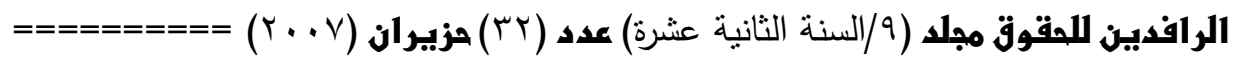

أما إذا لم يكن الالتزام أو الحق من مستلزمات ما استخلف فيه الخلف الخاص من

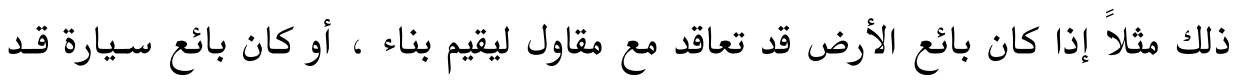

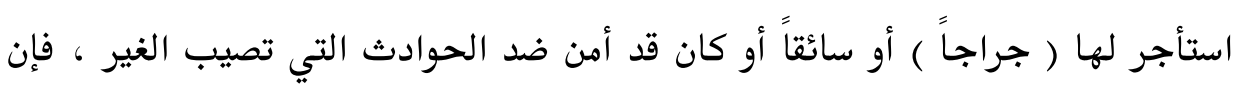

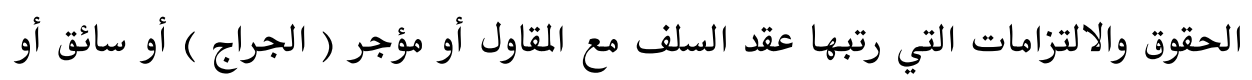

شركة التأمين لا تنتقل إلى الخلف الخاص (1)

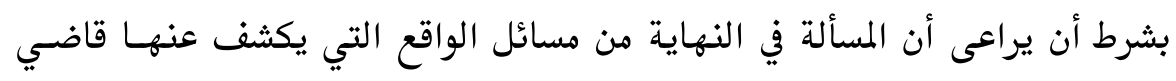

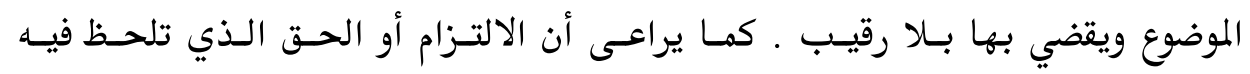

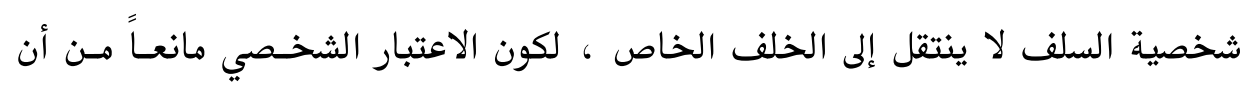

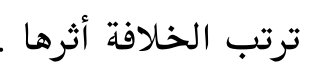

\section{المبحث الثاني

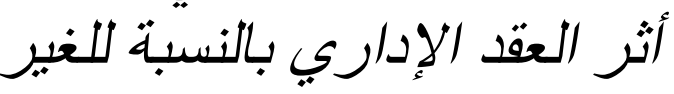

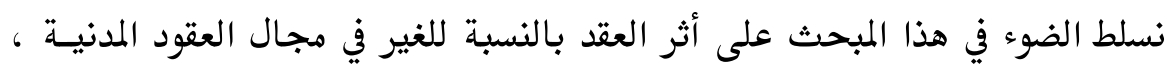

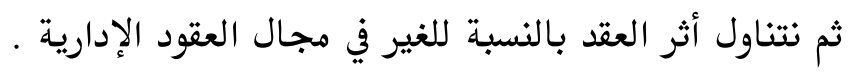

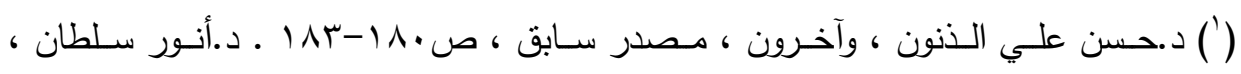

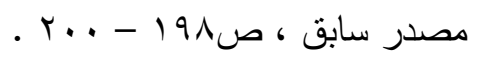




\section{المطل.}

\section{أثر العقد بالنسبة للغنبر (1)في العقود المدنبة التية}

القاعدة العامة : إن الغير الأجنبي لا يتأثر بعقد يبرمه غيره ولا تسري بحقه آثار من ذلك العقد ، فلا يتحمل من جرائه التزامات وقد لا يكسب من ورائه حقوق ـ وقد عـبر المشرع العراقي في القانون المدني عن هذا المبدأ في المادة ( ror ) التي نصت على أنسه (ألى

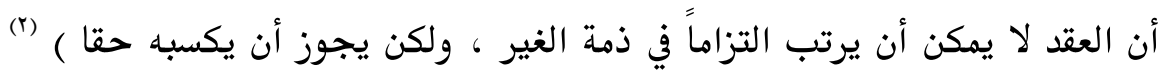
من خلال نص المادة أعلاه يتبين أنها تتضمن البحث في قاعـدتين مختلفتين تعتمـد الأولى على الجانب السلبي المتمثل بعدم سريان ما ينتج عن العقـد مسن التزامـات تجــاه

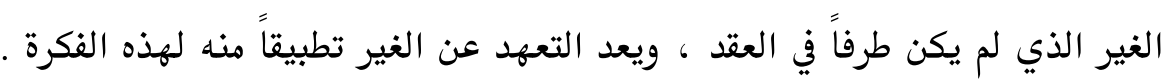

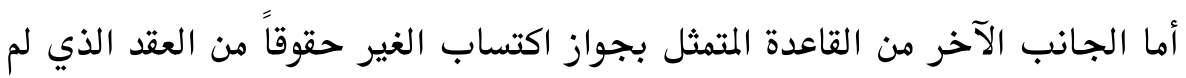

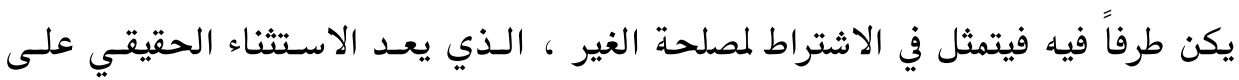
قاعدة نسبية أثر العقد ، بمعنى عدم انصرافه لغير المتعاقدين .

(') الغير لغةً : كلمة غير من حروف المعاني قد تكون نعتاً وقد تكون بمعنى لا ، وقد تكون

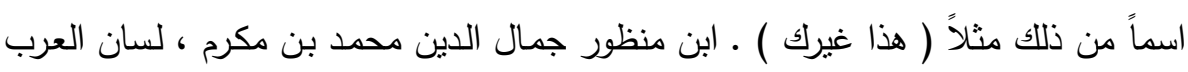

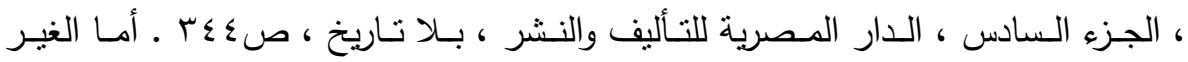

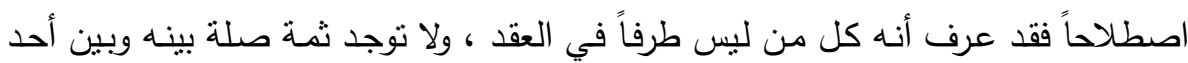

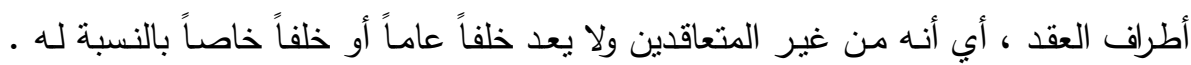

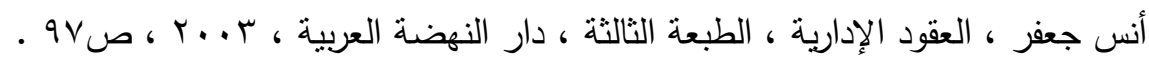

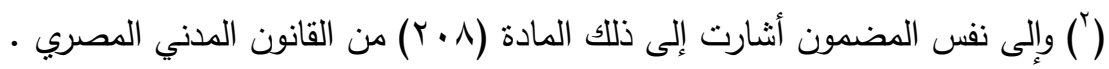




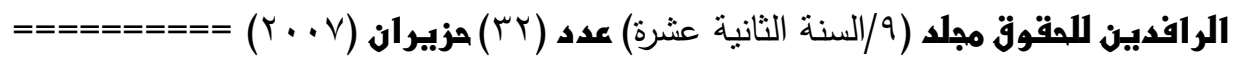

ومن هذا المنطلق ولكون الاشتراط لمصلحة الغير يشكل استثناءً حقيقيـاً على قاعـدة

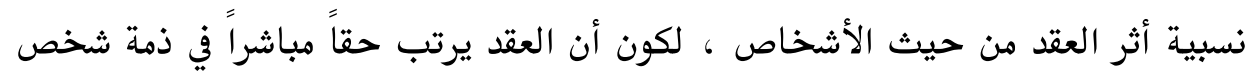

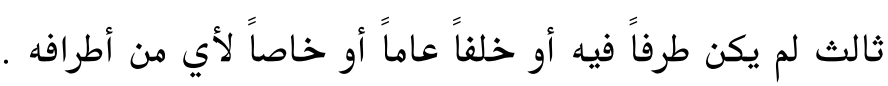

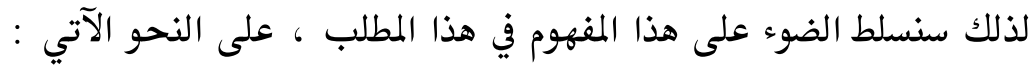

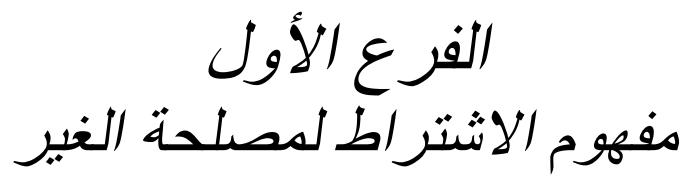

أولاًا : تعريفه :

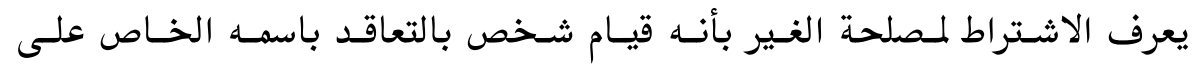

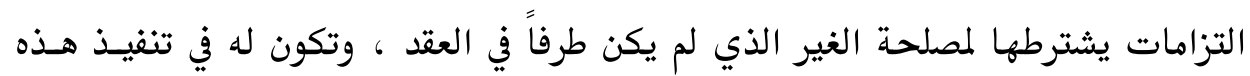

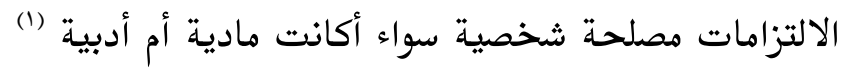

فالاشتراط لمصلحة الغير إذن هو تصرف قانوني يتم بين شخصين إلا أن تنفيذه يتعلق

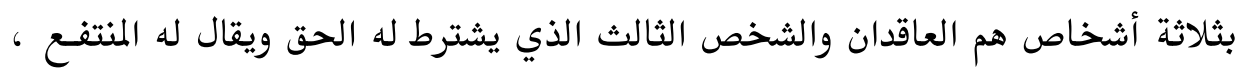
أما المتعاقدان فأحدهما يقـال لـه ( المشترط) وهـو الذذي اشترط الحسق ، والآخـر يقـال (المتعهد) وهو الذي التزم بإعطاء الحق للمنتفع .

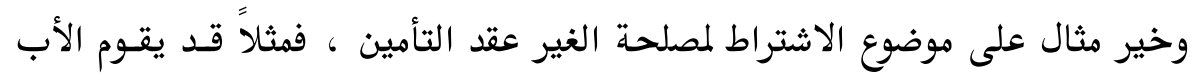

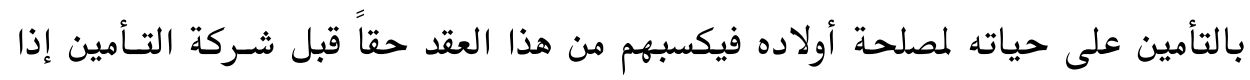

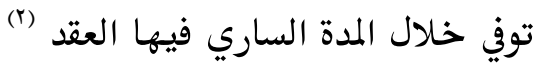

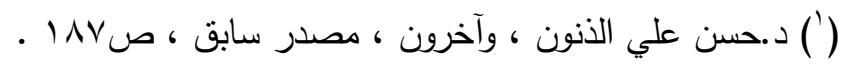

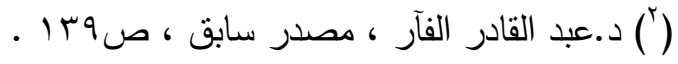




\section{الفر ع الثاني}

تمبيز الاشتر اط لمصلحة الغبر عن التعهر عن الغبر الغير أساس الاشتراط لمصلحة الغير يختلف عن أساس التعهد عن الغسير ، أن الاشـتراط لمصلحة الغير لا يتضمن عقدين كالتعهد عن الغير ، بل هو لا يشتمل إلا على عقد واحد

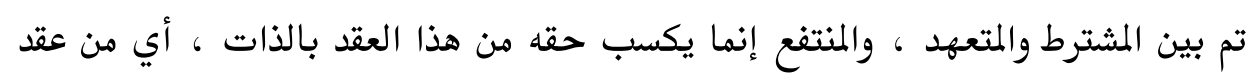

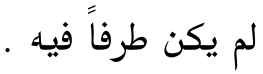

\section{الفر ع الثالث: \\ شروط تحقق قاعدة الاشتر اط لمصلحة الغبر}

حتى يتحقق الاشتراط لمصلحة الغير ، يجب أن تتوافر شروط ثلاثة وهي على الذحو

\section{الشرط الأول : المشترط يتعاقد باسمه لا باسم المنتفع :}

هذا هو الذي يميز الاشتراط لمصلحة الغير عن النيابة ، فالنائب وكيلاً كان أو ولياً أو فضولياً ، يتعاقد باسم الأصيل ، أما المشترط فيتعاقد باسمه . وبذلك يختلف المشترط عن الفضولي ، فالمشترط يتعاقد باسمه كما ذكرنا سـلفاً ، في

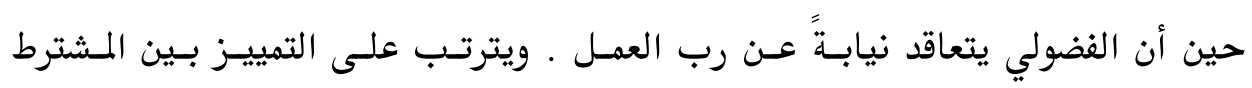
والفضولي نتائج مهمة منها :

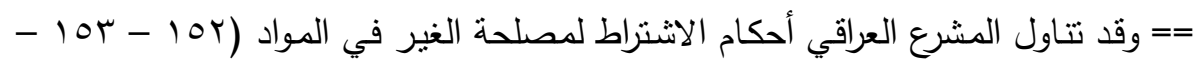

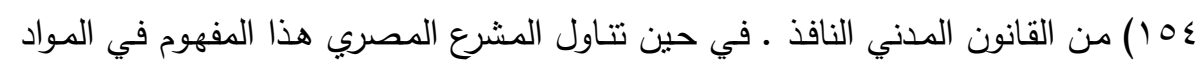

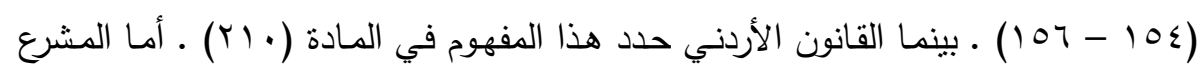

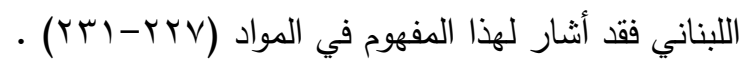




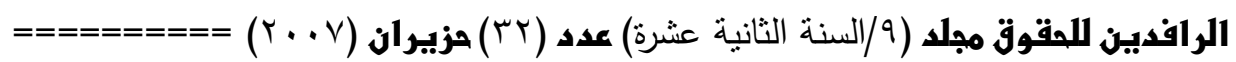

أولًا : : يجب أن يكون للمشترط مصلحة شخصية كونه يتعاقد باسمه ، أما الفضولي فهو على العكس من ذلك حيث يجب أن لا تكون له مصلحة شخـصية في إدارة شـؤون رب العمل ثانياً : كل شخص يستطيع أن يشترط لمصلحة الغير ما دامت لـه مسصلحة شخـصية في ذلك وليس كل شخص يستطيع أن يدير عمل الغير عن طريت الفضالة إذ لابد مسن قيـام ضرورة تقضي بذلك (1) الشرط الثاني : أن بكون للمنتفع حق مباشر : في هذا الحق المباشر تتجلى الفكرة الأساسية في الاشـتراط لمسلحة الغسير ـ إلا أنسه لكي يكسب المنتفع حقاً مباشراً يجب أن تنصرف إرادة العاقدين إلى تخويله ذلك الحق شخصياً .

أما إذا كان العقد يخول منافعه للعاقد ، في ذات الوقت الذي يفيد منه الأجنبي فلا نكون بصدد اشتراط ، كما إذا أمن صاحب السيارة ضد الحوادث ، فإنه يعقد عقداً لا اشتراط فيه لأنه إنما يسشترط لمـصلحتـه لا لمسصلحة المـصاب ، وإن أفـاد هـذا مسن مبلـخ التعويض الذي يستولي عليه المؤمن له من شركة التأمين والذي سيزاحمه فيه غسيره مسن (r) الدائنين

\section{الشرط الثالث : المشترط لله مصلحة شخصيـة في الاشتر اط للغير :}

حيث يجب أن يكون لمن اثترط لمصلحته مصلحة مادية أو أدبية من هذا الاثتراط، أما إذا لم تكن له مصلحة أو كانت له مصلحة غير مشروعة من هذا الاشتراط فذلك غير

(') د.عبد الرزاق السنهوري ، الوجيز في شـرح القانون المدني ، مصدر سـابق ، ص9 اب. TYY

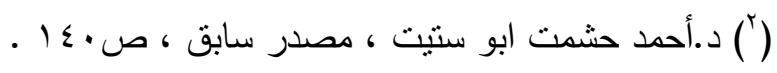


جائز . والمصلحة الشخصية هي الفرق الجوهري ما بين الفضالة والاشتراط لمصلحة الغير. واستناداً الى ذلك فإنه يصح التأمين لمصلحة الزوجـة والأولاد وكـذلك الاشـتراط لمـصلحة الفقراء أو العجزة أو لأي عمل آخر من أعمال البر لوجود المصلحة الأدبية للمشترط ، إلا أنه لا يعتد بعاشق يؤمن على حياته لمصلحة عشيقته لعدم وجـود المـصلحة المشروعة ، ويغترض أن في الاشتراط مصلحة مشروعة للمشترط حتى يثبت العكس (1)

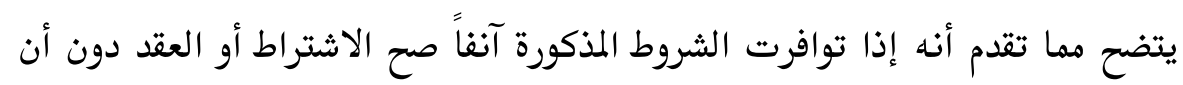
يشترط أن تقوم الأهلية لدى المنتفع لأنه ليس طرفاً في العقد ، والحق الذي يكتسبه مـن الاشتراط لا يتوقف على إرادته .

\section{الفرع عابع الر إبع

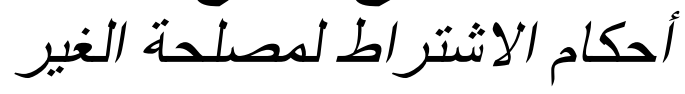

تتحدد أحكام الاشتراط لمصلحة الغير في علاقات ثـلاث ، تنـشأ بالاشـتراط ، هـي

علاقة المشترط بالمتعهد ، وعلاقة المنتفع بالمشترط ، وعلاقة المنتفع بالمتعهد .

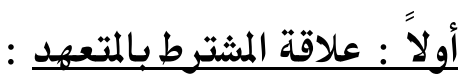

هذه العلاقة يحكمها عقد الاشتراط ، ومن حق كل منهم أن يطلب من الآخر الوفاء بالتزامه ، ففي عقد التأمين مثلاً يلتزم المشترط بـأن يـدفع للمتعهـد ( شـركة التـأمين ) أقساط التأمين في مواعيدها وتلتزم شركة التأمين بأن تقوم بما عليها من التزام كدفع قيمة

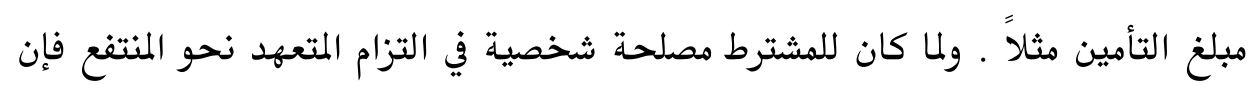

(') د.عبد القادر الفأر ، مصدر سابق ، ص. ـ1 . 


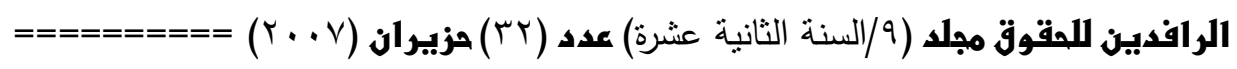

له أن يراقب تنفيذ هذا الالتزام لأنه ليس أجنبياً عنه ، كما أن له رفع دعوى باسمه لا

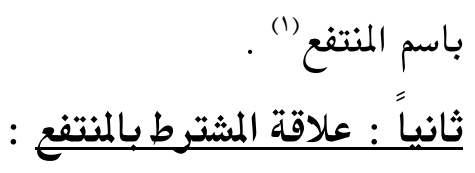

وقد يكون المشترط باشتراطه لمصلحة المنتفع أراد أن يتبرع له ، وقد يكون أراد أن

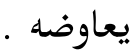

فإذا كان المشترط أراد التبرع للمنتفع ، كانت العلاقة بينههـا هي علاقـة الواهـب

بالموهوب له . إلا أن الهبة هنا لا يشترط فيها الشكل ، كونها هبة غير مباشرة ، ولكن

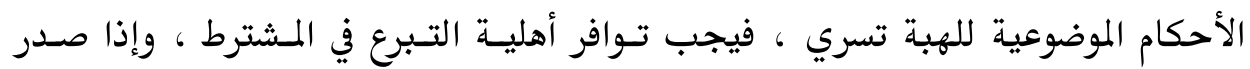

الاشتراط في مرض موت المشترط أخذت الهبة حكم الوصية ، كمـا يجهوز الطعـن فيهـا

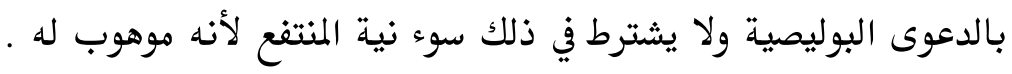

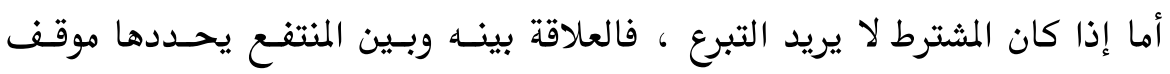

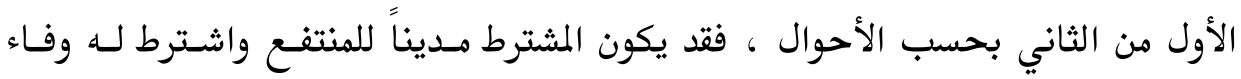

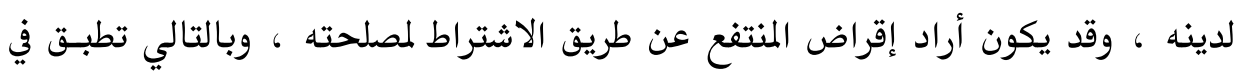

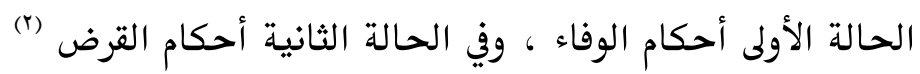

ثالثاً : علاقة المنتفع بالمتعهد :

تعد هذه العلاقة أهم ما في الاشتراط لمصلحة الغير لأنها هي التي تسبغ عليه طابعه

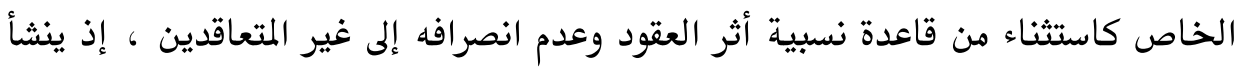
عن هذه العلاقة التي تقوم بين المنتفع وبين المشترط " حق مباشر " للمنتفع مصدره عقد

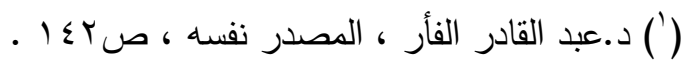

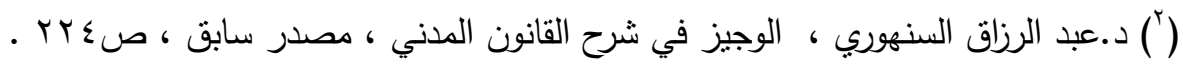


الاشتراط ، وهنا يظهر خروج على قاعدة نسبية أثر العقود ، فالمنتفع وهو لم يكن طرفـاً

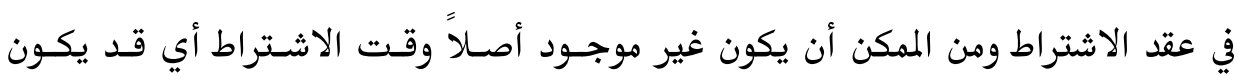

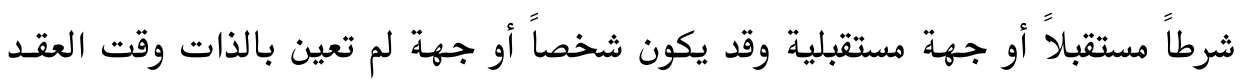
متى كان تعيينهما مستطاعاً عند إنتاج العقد أثره (1) ويترتب على أن للمنتفع حقاً مباشراً تلقاه من عقد الاشتراط ولم ينتقل إليه النتـائج الآتية :

أولًا : ليس لدائني المشترط شأن بهذا الحق حسال حياتـه أو بعسد وفاتـهـ بـل ينفـرد بـــ

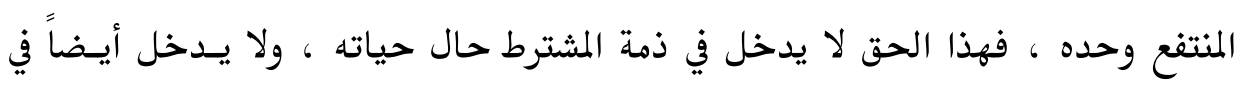
تركته بعد وفاته . ثانيًا : لا يجوز لدائني المشترط ( حـال حياتـه ) التنفيـذ على الحـق الـذي اشـترطهم مدينهم للمنتفع ، ولا يجوز لهم أن يستعملوا حق مسدينهم في نقـض الاشـتراط لكـون أن

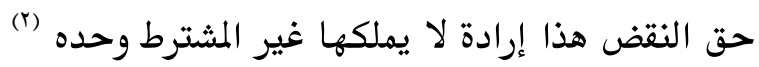

\section{الفر ع الخاهس \\ الاشتر اط لمصلحة الغير و العقود الإدارية النية}

السؤال الوارد في هذا المجال هو : هل بالإمكان تطبيق نظريسة الاثـتراط لمصلحة

الغير في مجال العقود الإدارية ؟

في الواقع إن الاستناد الى هذه النظرية في نطاق العقود الإدارية لا يمكن الأخـذ بـــ

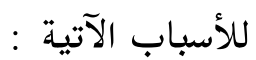

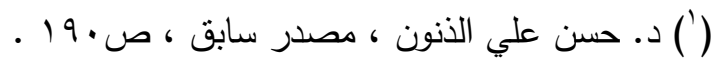

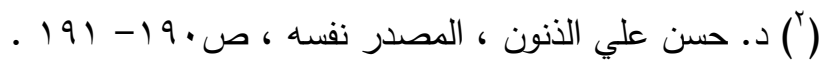




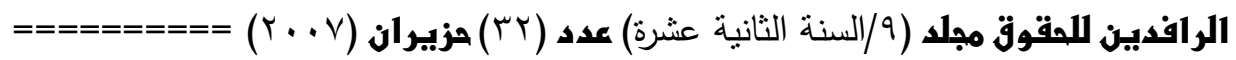

أولاًا : يشترط لتطبيق نظرية الاشتراط لمصلحة الغير أن يكون المستغيد معينـاً أو ممكن

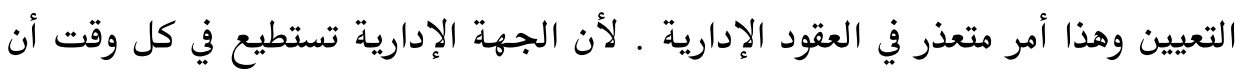

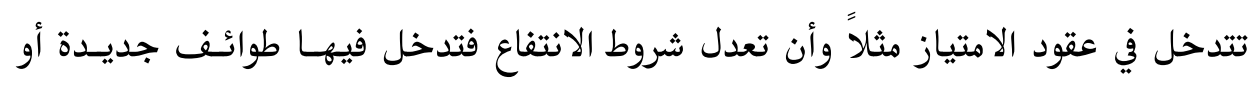
تنقص من الطوائف القديمة (1)

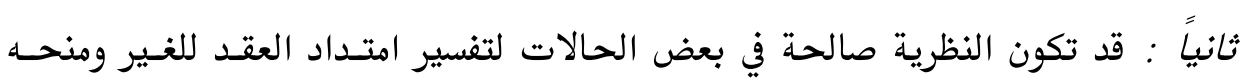

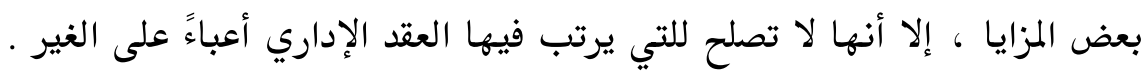

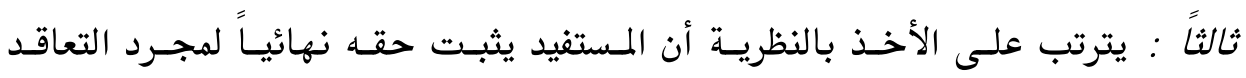

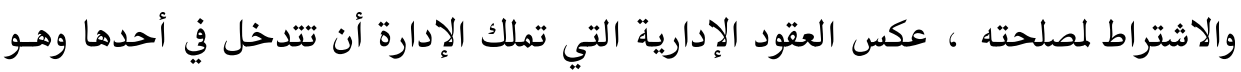

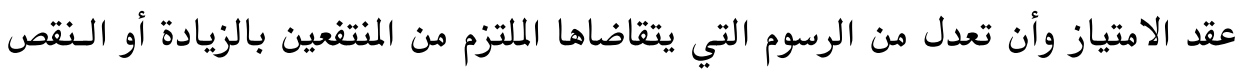

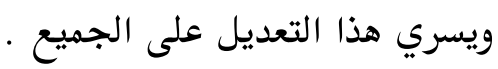
رابعًا : يترتب على الأخذ بهذه النظرية أن يكون للغير حق مباشر كما أسلفنا ، ويكون

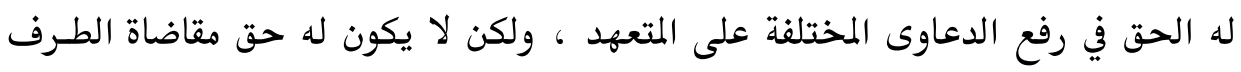

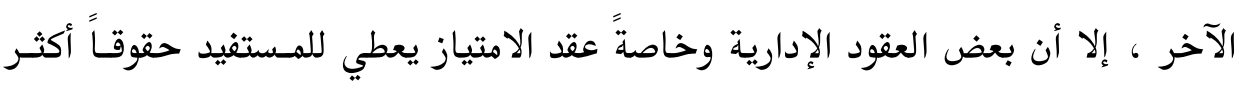

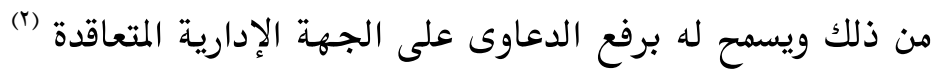

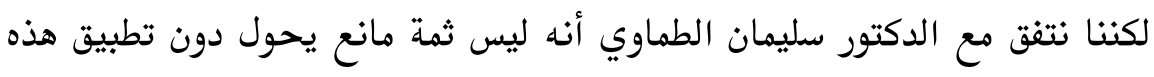

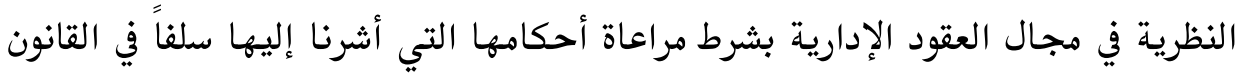

(') د.سليمان الطماوي ، الأسس العامـة للعقود الإدارية ، (دراسـة مقارنة) ، الطبعة الرابعة ،

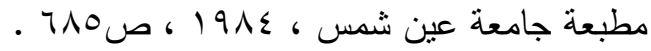

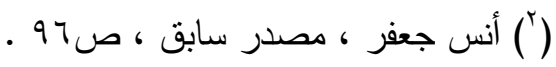


المدني ، إلا أن هذه الذظرية لا تصلح أساساً لتبرير امتداد آثار الغسير لا في مجـال عقـود

الامتياز ، ولا في الحالات التي لا تتوافر فيها الشروط الواردة في المجموعة المدنية (1)

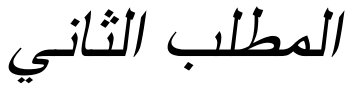 \\ أثز العقد بالنسبة للغبر في العقود الإداربية إنية}

قد يثأر تساؤل هل بالإمكان سريان القواعد المطبقة على الغسير في القـانون الخـاص على معنى الغير في العقود الإدارية ؟ بمعنى هـل ينطبـق معنسى الغسير في مجـال العقـود المدنية على العقود الإداريـة ؟

وللخصوصية التي تتمتع بها العقود الإدارية ، نرى أن معنى الغير يختلف نوعاً مـا عن ما تم الإشارة إليه سلفاً تجـاه الغير في مجال العقود المدنية . وبالتالي توجد صسوبة في تحديد الغير كون أحد أطرافه تكون إحدى الجهات الإدارية . لذلك أثير التساؤل عن ما هي الجهات الإدارية التي تعد من الغير بالنسبة للعقود الإدارية ؟

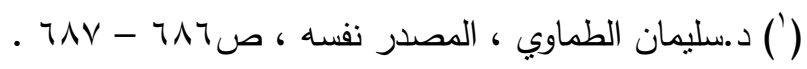

(") يعرف العقد الإداري بأنه ذلك العقد الذي بيرمه أحد الأشخاص المعنوبـة العامـة لإدارة مرفق عام ابتغاء تحقيق مصلحة عامـة ، متبعـاً في هذه الأسـاليب المقررة في القانون العام بمـا يعني احتوائه على شـروط غير مألوفة الاتبـاع في عقود القانون الخـاص . حكم المحكمـة

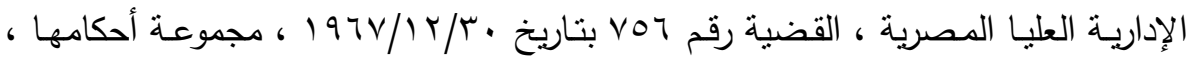
ص اسم 1 . د.سعاد الشرقاوي ، العقود الإدارية ، دار النهضة العربية ، 1999 ، صده . د.عمر حلمي ، دكتور ربيع فتح الباب ، المبادئ العامـة في العقود الإدارية ، دار النهضة

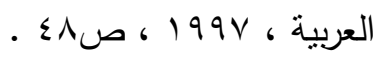




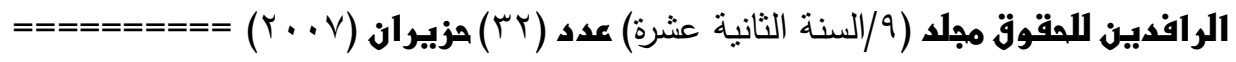

وفي الواقـع أن الغسير في مجــال العقـود الإداريـة قـد يكونسوا مـن أشـخاص القـانون

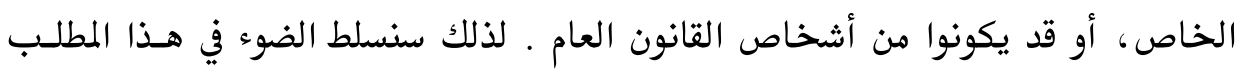

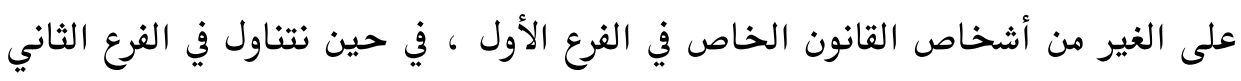

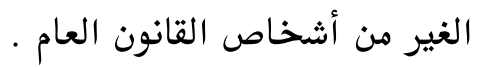

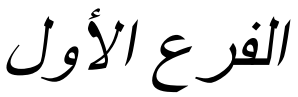

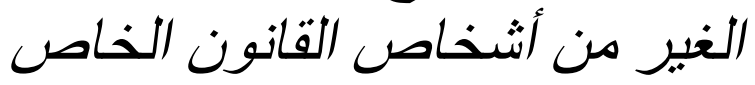

يمكن تقسيم الأشخاص من حيث علاقتهم بالمرافق العامة إلى ثلاث طوائف :

الطائفة الأولى : لئن

يشمل الأفراد الذين يتولون المرافق العامة والمشروعات العامة أو يعملون في خدمتها،

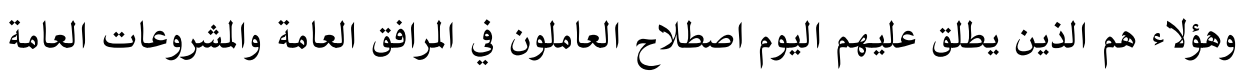

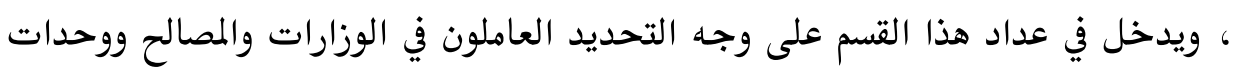
الإدارة المحلية والهيئات العامة والمؤسسات العامة وما يتبعها من شركات عامة .

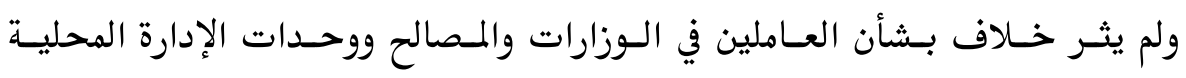

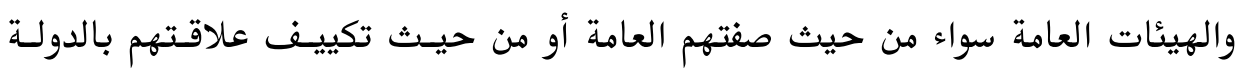

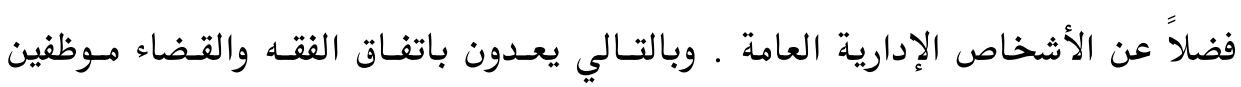

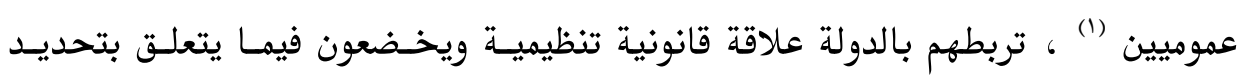
حقوقهم والتزامهم لأحكام القوانين التي تنظم شؤونهم .

(') يعرف الموظف العام بأنه الموظف الذي يتولى مقاليد وظيفية بموجب سند قانوني إما أن

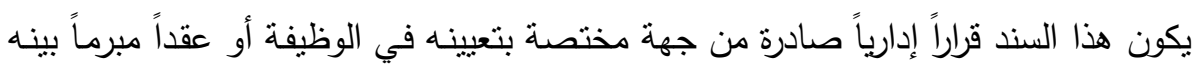

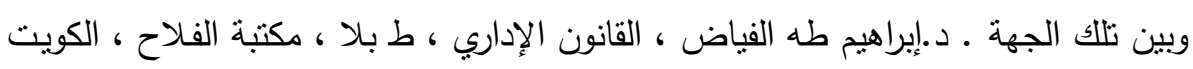


أما بالنسبة للعاملين في المؤسسات العامة وما يتبعها من شركات عامة فقد اختلف الرأي بخصوص تحديد صفتهم وطبيعة العلاقة التي تربطهم بالشركة العامة أو المؤسسة العامة أو التي يعملون في خدمتها (1) الطائفة الثانيـة

يشمل الأشخاص الذين يعاونون في تنفيـذ المرافـق العامسة والمـشروعات العامسة سـواء بالاشتراك في العمل مع السلطات والهيئات القائمة على إدارة هذه المرافق والمشروعات أو بالانفراد بالقيام ببعض الأعمال لمصلحة المرافق العامة والمشروعات العامة . من ذلك مثلاً الأشخاص الذين يتعهدون بتوريد مواد وأدوات لازمة للمشروع العـام ومتعهدو النقل الذين يعهد إليهم بنقل الأدوات أو المهمات وغيرها من المنقولات لمصلحة

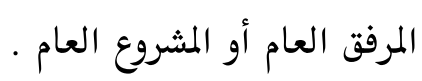
ونتفق مع الدكتور فكري أحمد سنجر بأن هؤلاء الأشـخاص وأمثـالهم يعتـبرون في علاقتهم بالسلطة أو الشخص الإداري القائم على إدارة المرفق العـام أو المسروع العـام في

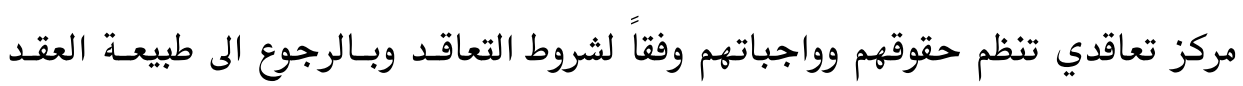
المبرم بينهم وبين المرفق أو المشروع وما إذا كان يعتبر عقداً مدنياً أو عقداً إدارياً . وبالتالي فإن من الطبيعي أن يسستخدم هلتـزم المرفـق العـام مجموعــة مـن العـاملين يساهمون بمساعدتهم في تنفيذ واجباتهم تجاه الإدارة ، وبالتالي فإن أولئكك الأشـخاص

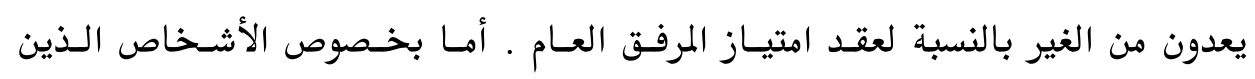

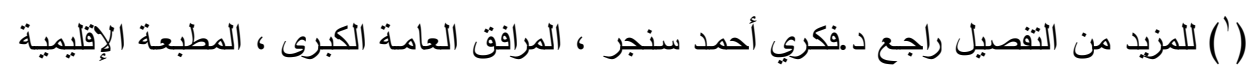

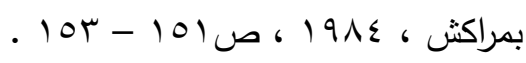




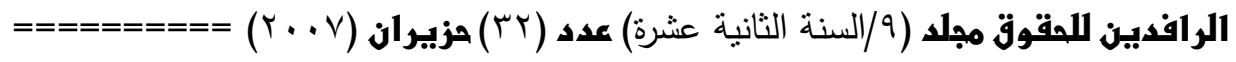

يستخدمهم الملتزم في عقد المرفق العام فـإن هنـاك اختلافـاً بـين الفقهـاء تجـاه مركـهم

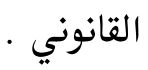

حيث عدهم الفقيه الفرنسي ( ديجي ) موظفين عموميين ولاسيما في المرافق العامـة

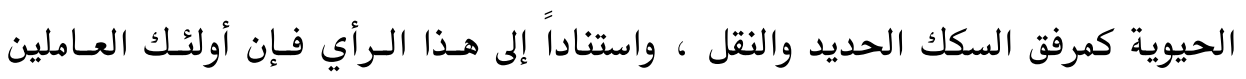
يخضعون للقوانين والأنظمة الخاصة بالموظفين(")

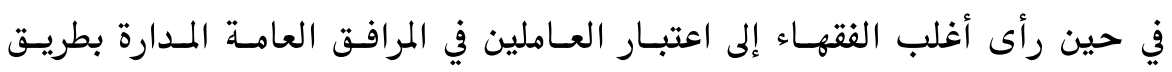

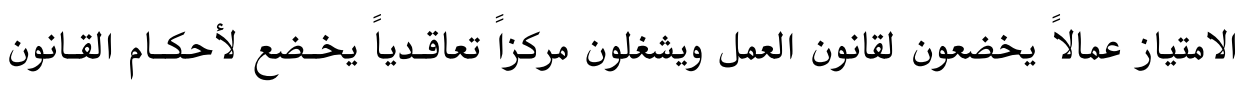

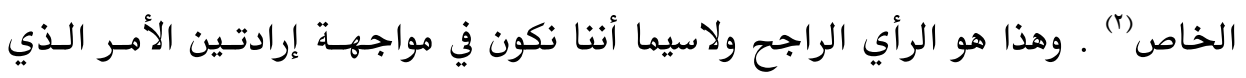

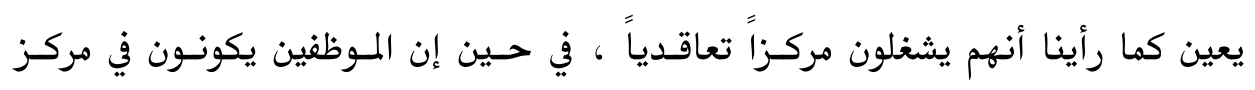

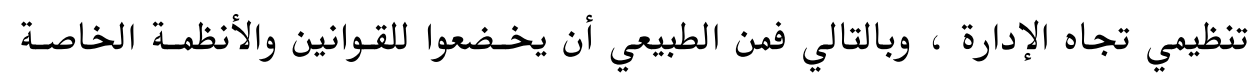

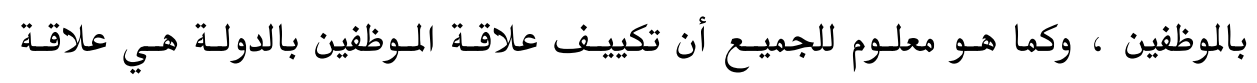

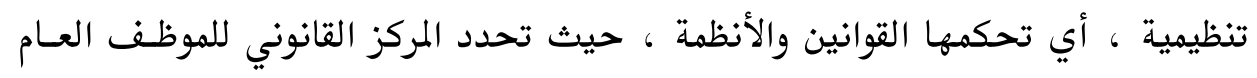
بما يتضمن من حقوق وواجبات بصرف النظر عن صفة شـاغلي الوظيفـة العاهـة وترتيبـاً

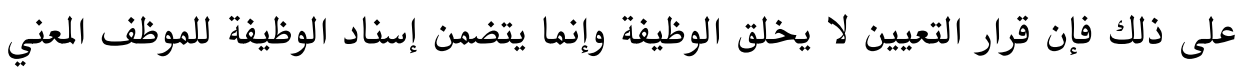

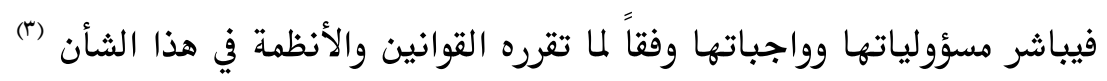

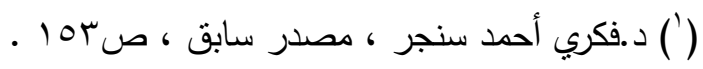

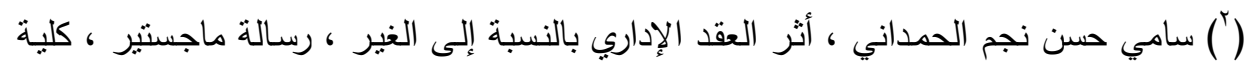

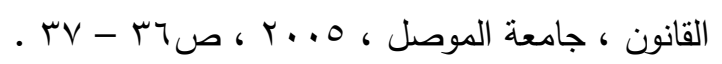

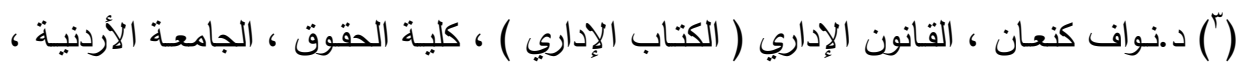

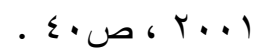


تشمل هذه الطائفة الأفراد الذين يفيدون مما تحققـه المرافـق العامـة والمـشروعات

العامة من نفع عام أو مما تقدمه من سلع وخدمات وهما قسمان :

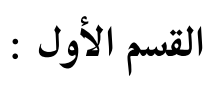

يشمل الأفراد الذين يفيدون ممـا تحققـهـ المرافـق العامـة والمـشروعات العامـة مـن

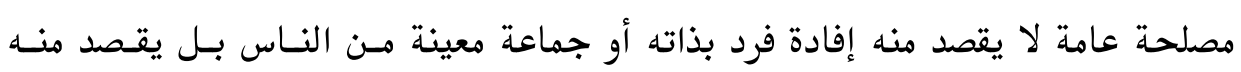
إفادة المجتمع بصفة عامة دون تحديد أو تخصيص .

وبالتالي فإن المصلحة العامة التي تفيد هذا القسم مسن الأشـخاص لا يتحقق عـن

طريق تقديم حاجة معينة لشخص بذاته أو أشخاص معيسنين بـذواتهم بـل يتحقـق عـن طريق ما يشيعه إنشاء المرافق العامة من نظام وعدل وتنميسة اقتصادية وتقـدم في جميـع أنحاء الدولة، بحيث ينال كل شخص مقيم على أرض الدولة حصته منسه بطريسق غـير مباشر بحكم وجوده في دولة متقدمسة تحققـت لهـا كـل وسـائل القـوة والرخـاء والتقـدم

الاقتصادي والاجتماعي والسياسي ').

وهذه المصلحة العامـة نراهـا متحققـة في مرافـق الـضبط الإداري الـتي تقـوم باتخــاذ إجراءات يكون هدفها المحافظة على الذظام العام (؟) ، وكذلك مرافـق الـصحة والـدفاع والقضاء من عدالة ورخاء في أنحاء الدولة كافة . لذلك يطلق على أعـضاء هـذا القسم اسـم ( المستفيدون ) تمييـزاً عـن غيرهـم ممسن يستفادون من الخدمات الـتي تقـدمها المرافقق العامسة ـ أمـا بخـصوص المركز القـانوني

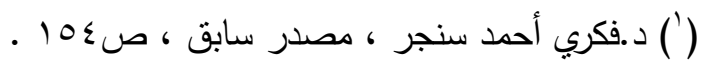

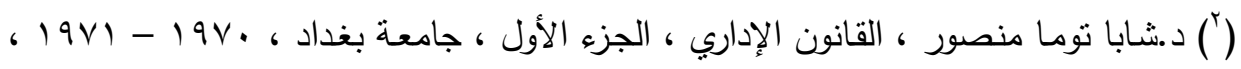




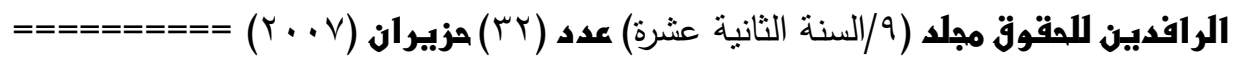

للمستفيد فإننا نتفق مع ما ذهب إليسه الـبعض (1) ، مسن أن المستفيد في مركز تنظيمي

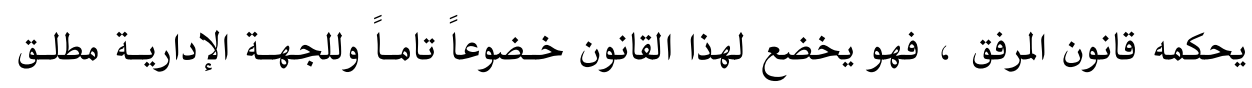
الحرية في تعديل قانون المرفق ونظامه .

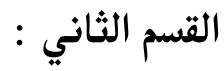

يتضمن الأشخاص الذين يفيدون مما تقدمه المرافق العامة من سلع وخدمات ، فضلاً

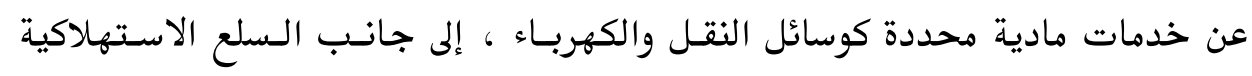
التي تقدم من قبل تلك المرافق لأفراد المجتمع كافة .

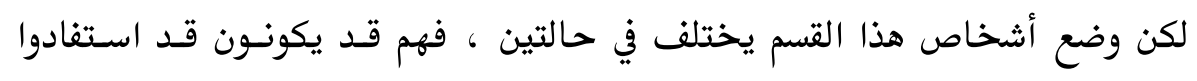

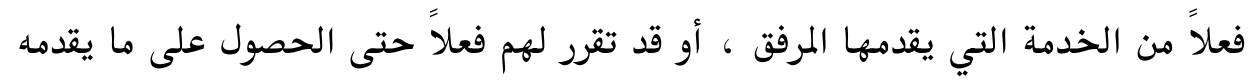

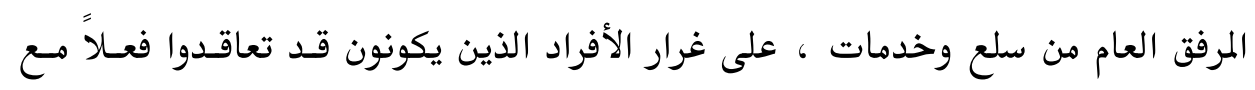

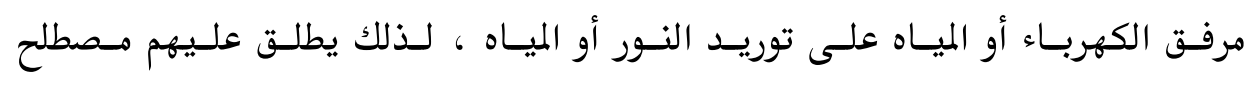
(المنتغعون) (")

ورغم الخلاف الحاصل حول تحديد المركز القانوني للمنتفعين ، فإننا نرى أنهـم في

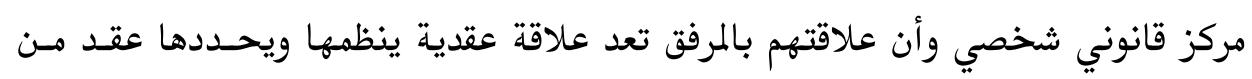

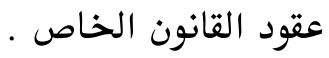

(') دمحمد فؤاد مهنا ، حقوق الأفراد إزاء المرافق العامة ، بحث منشور في مجلة مجلس الدولة التهائ

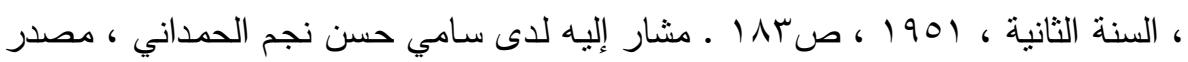

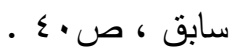

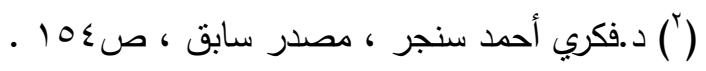


لكن قد يكونون مجرد مرشحين للحصول على السلعة ، وبالتالي فإن هـؤلاء يطلـق

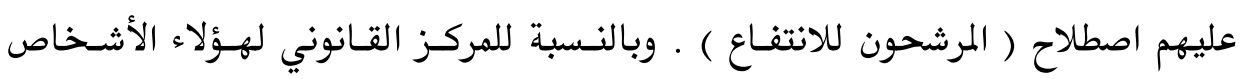

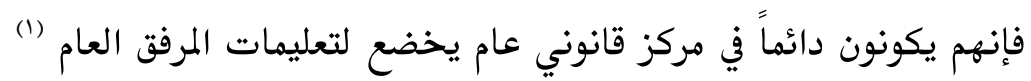
لكن بخصوص المرافق التي تدار بطريق الامتياز ورغم الخلاف الحاصل بين القضاة والفقه حول المركز القانوني ( للمرشحين للانتفاع ) ، إلا أن القضاء الفرنسسي قد حسم لهـ

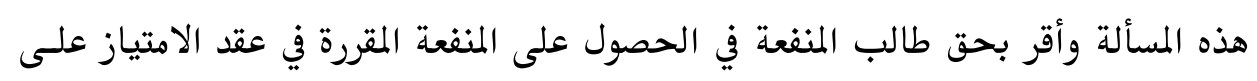

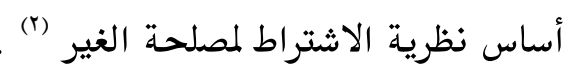
رغم أن البعض يرى عدم إمكانية تطبيق شروط هذه النظرية بالنسبة لآثار العقد الإداري

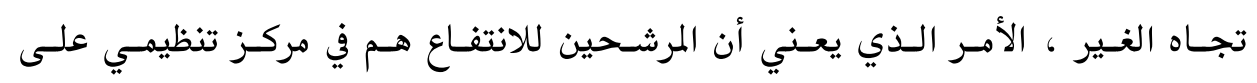
المستفيدين يحكمه قانون المرفق (")

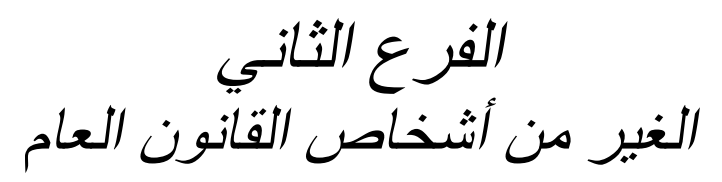

لا يـثير تحديسد فكـرة الغسير ( La notion de tiers ) أي صعوبة فيمـا يتعلـق بالأشخاص الذين يتعاقدون مع الإدارة أو غيرهم ممن يمسهم العقد . وبالتالي لما كانت هناك صعوبة بخصوص تحديد جهات الإدارة التي تعد من قبيل الغير بالنسبة إلى عقد إداري معين ، كون أن مجلس الدولة الفرنسسي قـد عَّدـ في تـاريخ

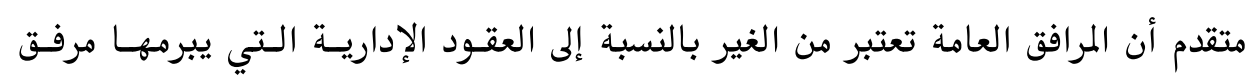

(') د.فكري أحمد سنجر ، مصدر سابق ، صعأ100 100 .

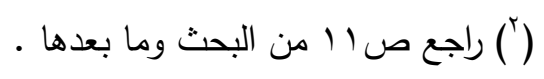

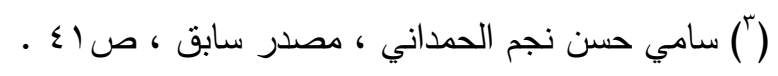




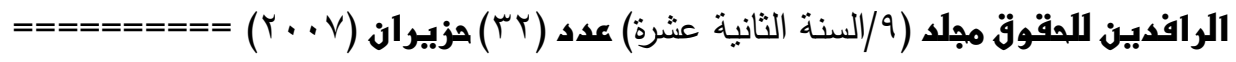

معين ، وذلك بصرف النظر عن تمتع تلك المرافق بالشخصية المعنوية ، وبالتـالي تعتـبر الوزارات الأخرى ، من الغير بالنسبة إلى العقود التي يبرمهــا وزيسر معسين فيمـا يتعلـق بشؤون وزارته (1)

لكن هذا الاتجــاه هجـره القـضاء الإداري الفرنسسي منـذ فـترة ليسست بالقـصيرة ، وبالتالي أصبحت فكرة الغير في نطاق العقود الإدارية بـصورة خـاصـة ، ونطـاق التذظيم الإداري بصورة عامة مرتبطة بغكرة الشخصية المعنوية (r) وبالتالي فإن جهة إداريـة معينة لا تعد من قبيـل الغسير بالنسبة إلى جهـة إداريـة أخرى إلا إذا كانت كل جهة فيها تابعة لشخص معنوي مستقل . فـالوزارات لا تعتـبر من الغير بالنسبة إلى الدولة ، كون أن كل وزارة لا تتمتع بشخصية مستقلة عن شخصية الدولة ، إلا أن المحافظات والمراكز والمدن والأحياء والقرى والهيئـات العامسة تعـد مسن الغير بالنسبة إلى الدولة ، فضلاً عـن العقـود الـتي يبرمهــا كـل شـخص عـام مسن هـذه

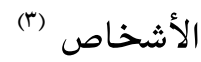

(') د.سليمان الطماوي ، مصدر سابق ، ص I97 - 79 ا 79 ـ د.عبد العليم عبد المجيد مشرف ،

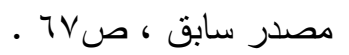
( ) يقصد بالثخصية المعنوية العامة بأنه الثخص الإداري الذي تثبت له أهلية اكتساب الحقوق والتحمـل بالالتزامـات ، ويمـارس نـشاطه مـن أجـل تحقيـق المـصالح العامـة ـ للمزيـــ مـن التفاصيل حول الثخصية المعنوية راجع د.عاصم أحمد عجيلة ، د.محمد رفعت عبد الوهاب ، القانون الإداري اليمني ، الطبعة الثالثة ، جامعة صنعاء، ، 191 ، ص ص0 ، وما بعدها . وعرفها الفقيه الفرنسي Louis Rolland بأنها حيلة قانونية وراءها حقائق لا ربب فيها تتمثل بأثخاص وأموال مخصصة لتحقيق غرض معين •

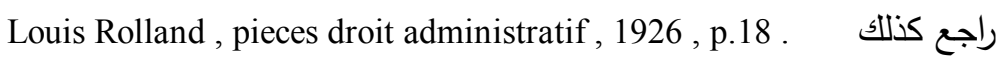
Marcel Hourio, précis de droit administratif et de droit puplic, 1933 , p.42 .

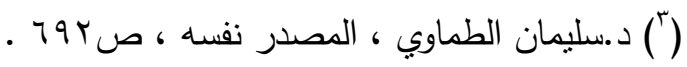


وبالتالي إذا كانت الجهـة الإداريسة المتمتعـة بالشخـصية المعنويسة تتمتـع باسـتقلال نسبي لكنها ترتبط برابطة عضوية تدريجية مسع مؤسسات الدولـة ، وقـد تلتـزم جهــة إدارية تعد من قبيل الغير بتـصرفات جهـة معينـة نتيجـة مخالفـة قواعسد الاختـصاص

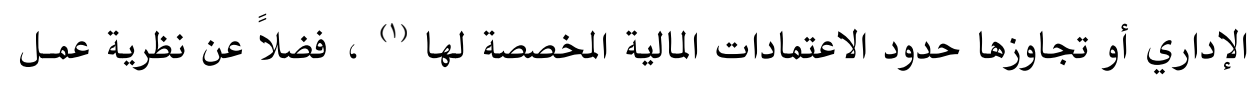
الأمير القائمة على أساس المخاطر الإدارية ، حيث تظهر فكرة الغير بصورة جلية في هذه : الحالات :

\section{الحالة الأولى : مخالفة قواعد الاختصاص :}

يقصد بقواعد الاختصاص تلك القواعسد الـتي تحسدد الأشـخاص أو الهيئسات الـتي تمتلك إبرام التـصرفات العامسة ، وهسي قواعسد تحمسي المسصلحة العامسة (r) . ومخالفـة الاختصاص من حيث الموضوع تكون بمباشرة الجهـة الإداريـة اختـصاصات ليسست مسن أعمال الإدارة (") ، فيكون حال الإدارة في هذه الحالة شبيهاً بحالة المتعهد عـن الغسير . لكن قواعد الاختصاص تعد من الذظام الذي لا يجوز الإتفاق علسى مخالفتـه ، وبالتـالي فإن الشخص المتعاقد مع الجهة الإدارية غير المختصة لا يمكن أن يستفيد من ذلك العقد ولا يمكن الاحتجاج به على الغير ما لم يكن حسسن النيـة وقـد تلتـزم الجهــة الرئاسية

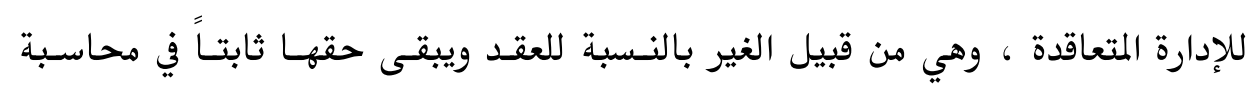
الموظفين . n

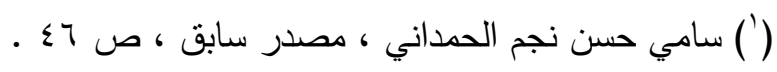

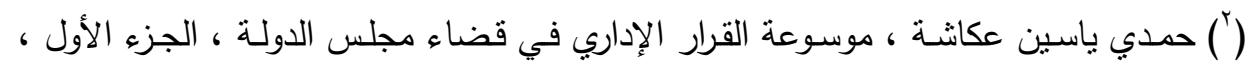

$$
\text { . OV } \leqslant \text { ص ، r... }
$$

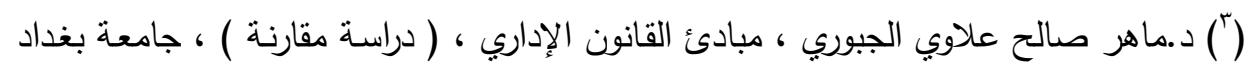

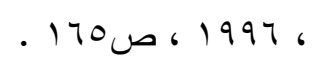




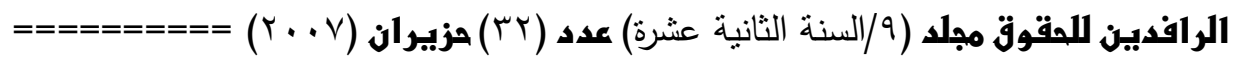

\section{الحالة الثانية : حالة تجاوز الإدارة لحدود مخصصاتها المالية :}

في هذه الحالة أو عندما تقوم الجهة الإداريـة بـصرف أهوال لتغطيسة عقد إداري

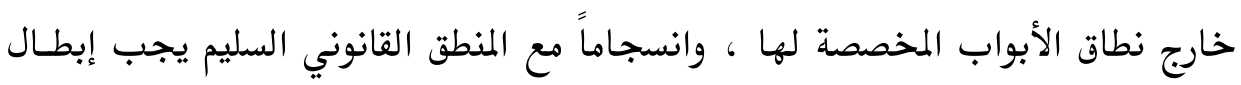

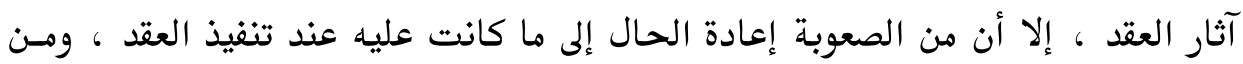

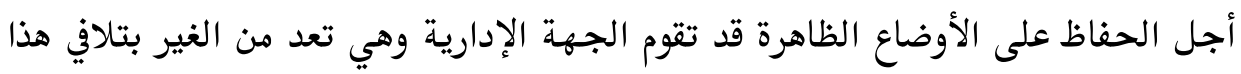

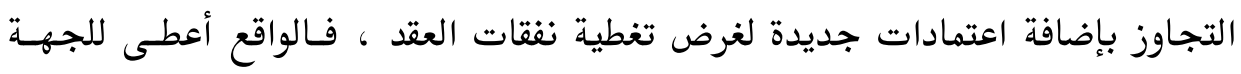

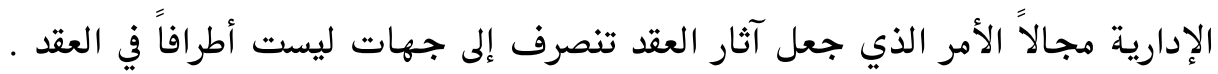

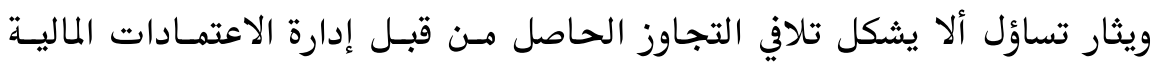

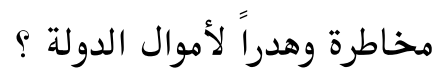

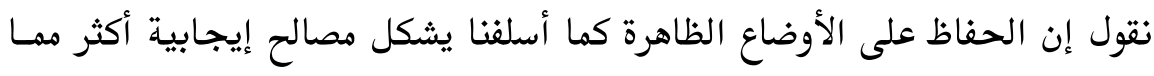

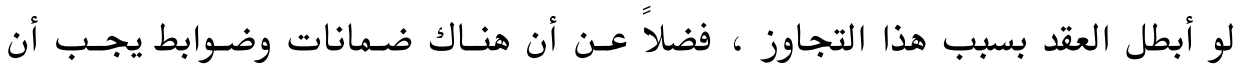

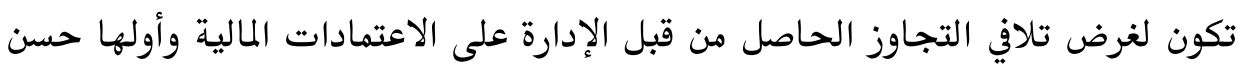

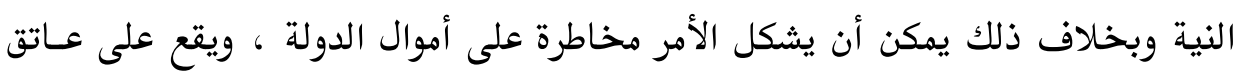
الرقابة الإدارية والقضائية دور كبير في معالجة هكذا حالات .

\section{الحالة الثالثة : نظريـة عمل الأميد :}

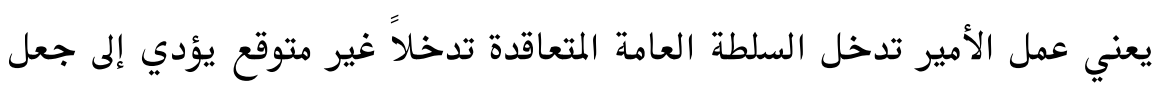

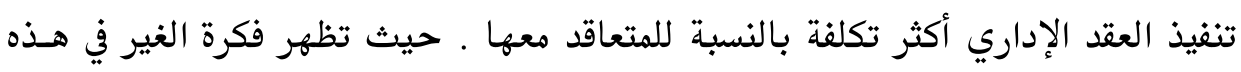

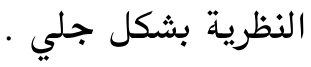

ويقتضي تطبيق هذه النظرية في نطاق العقود الإدارية تغير الظروف بـسبب إصدار

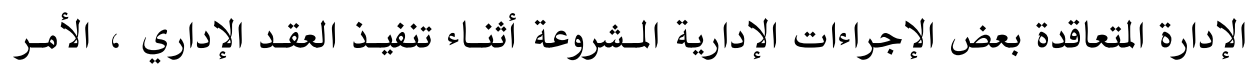


الذي يؤدي إلى إخلال بالتوازن المالي للعقد - إلى إقرار حق المتعاقـد في الحـصول على التعويض الذي يمكنه من تنفيذ التزاماته التعاقدية وإعادة التوازن المالي للعقد إلى حالته

الأولى قبل حلول هذه الإجراءات ، وذلك رغم عدم ارتكاب الإدارة خطأ ما (1). ونتفـق مـع الـبعض (r) ، الـذي ذهـب إلى القـول إن مـن أهـم الأمسور الـتي يمكـن الاستدلال بها على كون هذه الجهة الإدارية أو تلك تعد من الغير بالنسبة للعقود الـتي تبرمها جهة إدارية أخرى هو تمتعها بالشخصية المعنوية ، فكل شخص معنسوي عـام إقليمياً كان أو مرفقياً يكون من الغير تجاه تصرفات شخص معنوي عام آخر وإن ارتبط إنس

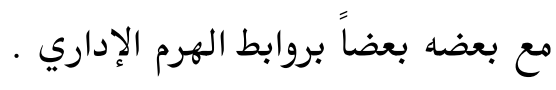

\section{المبحث الثالث}

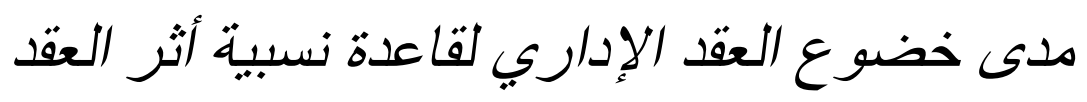
رأينا سلفاً أن العقد المدني يخضع لقاعدة نسبية العقد في آثاره ، بمعنى أن العقد لا

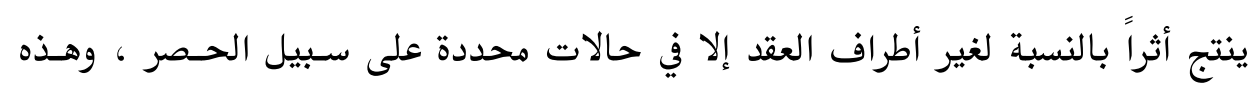
الحالات هي الخلف العام والخلف الخاص (") ، وبشروط خاصـة تمست الإشـارة إليهـا سلفاً .

وقد أثير التساؤل بالنسبة للعقد الإداري هـل تطبـق عليـه قاعسدة نسبية أثـر العقـد

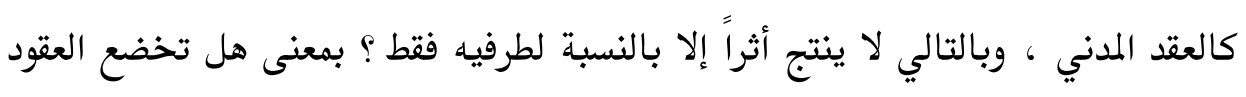

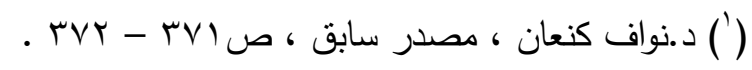

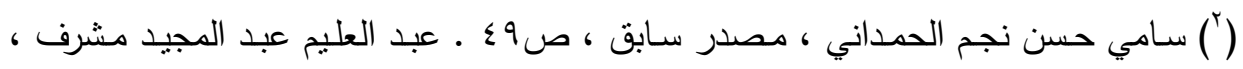

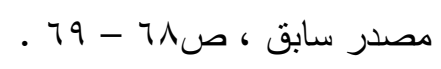

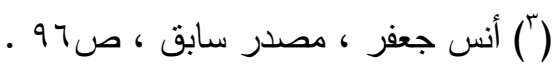




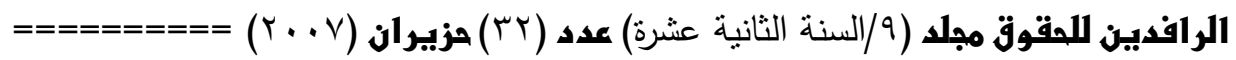

الإدارية لقاعدة نسبية أثر العقد شأنها في ذلك شأن العقود المدنيـة ، وبالتـالي لا ينـتج

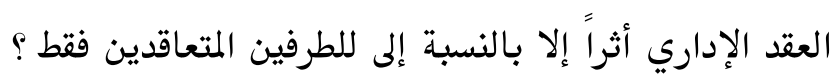

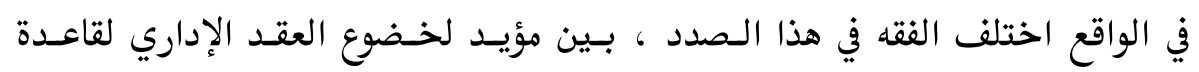

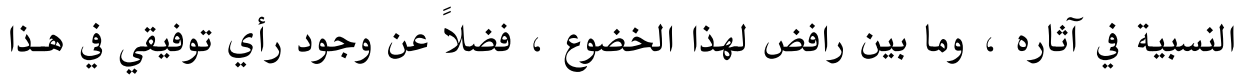

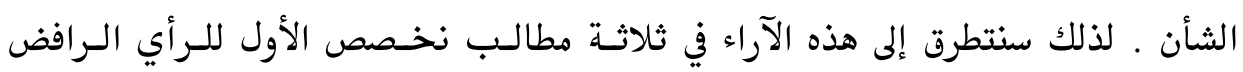

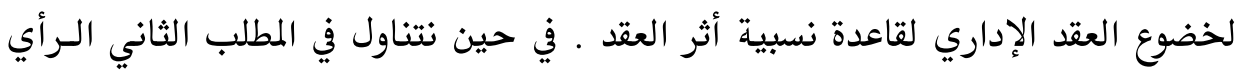

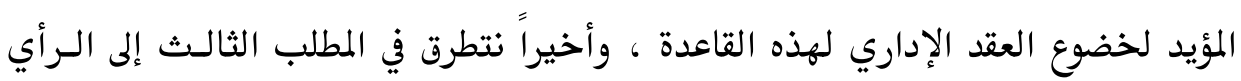

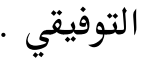

\section{المطلب الأول}

الرأي الرافض لخضوع العقد الإداري لقاعدة أثر نسبية العقد

ذهب أنصار هذا الرأي إلى القول بأن العقد الإداري لا يخضع لقاعدة نسبية أثـار

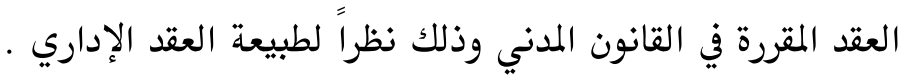

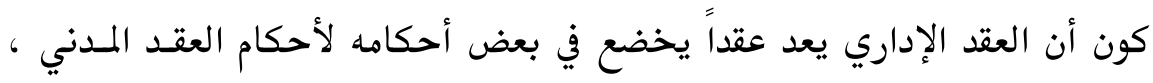

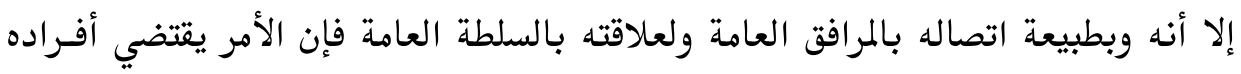

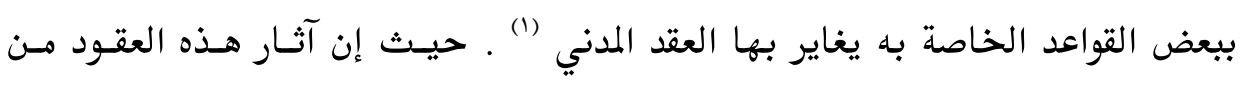

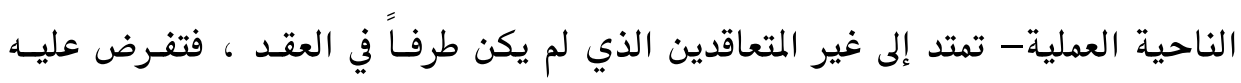

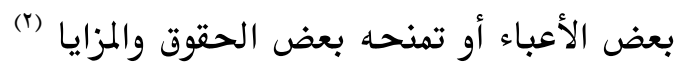

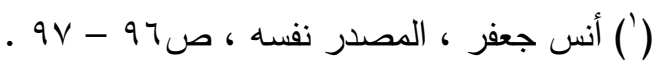

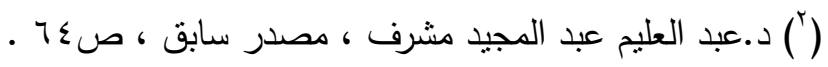


وفي هذا الشأن يرى الفقيه الفرنسي بكينو ( peqaignot ) أنه من غير الجائز التقيد بالقاعدة المدنية التي تقضي بقصر أثار العقود على أطرافها ، كما أنه من غسير المجـدي في نظره محاولة اكراه نظرية الاشتراط لمصلحة الغير المدنية ، وتحوير أحكامهـا بحيـث

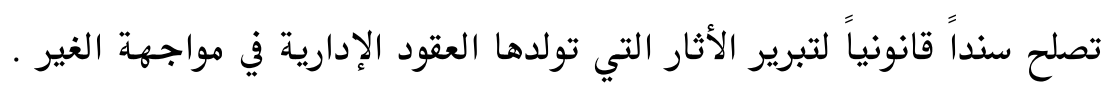

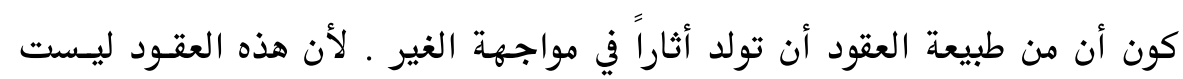

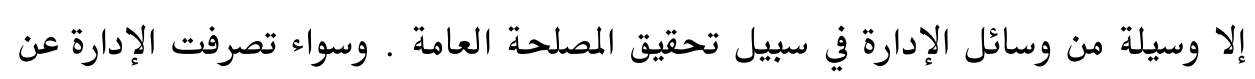

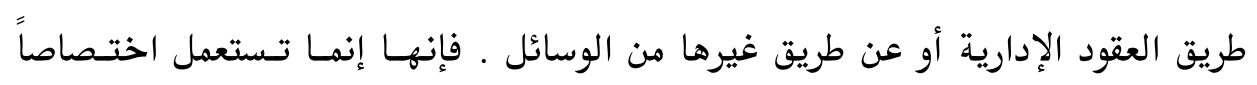
تستمده من القوانين والأنظمة ، وبالتالي فإن من شـأن ممارسـة هـذه الاختـصاصات أن تولد حقوقاً والتزامات في مواجهة الأفراد (1) كما يرى الدكتور سليمان الطمـاوي ، عـدم امكانيـة خـضوع العقـد الإداري لقاعـدة

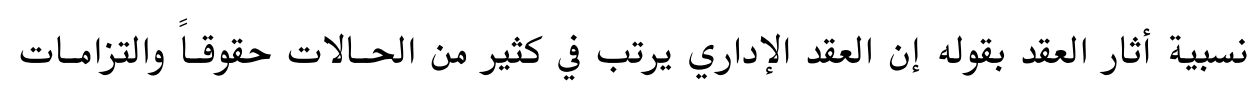

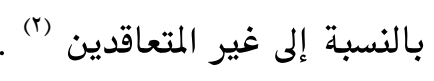

\section{المطلب الثاني}

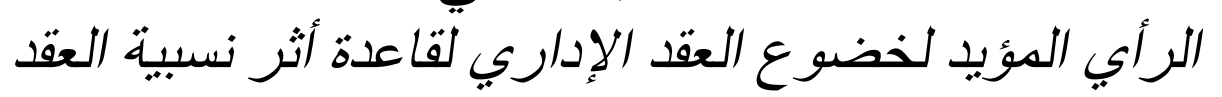

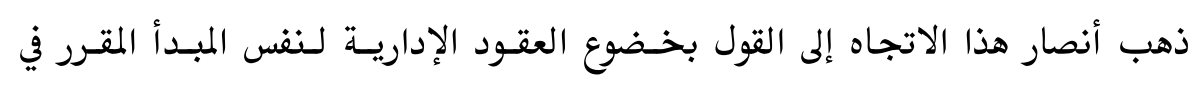

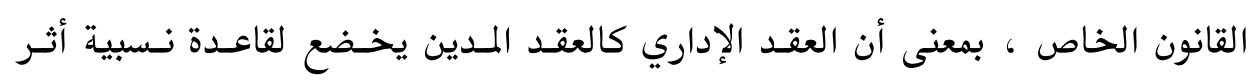

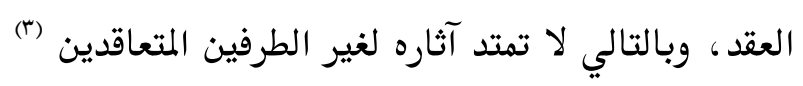

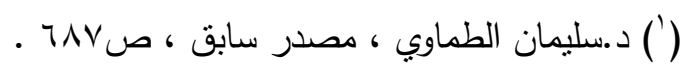

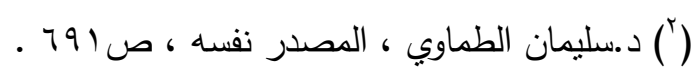

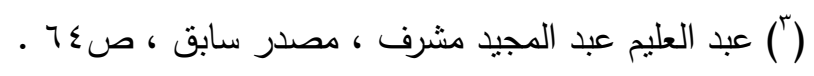




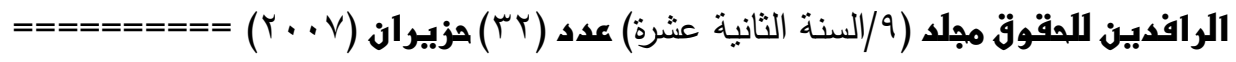

ومن هذا الرأي الفقيه الفرنسي دي لوبادير ، حيث يستند إلى أحكام مجلس الدولة

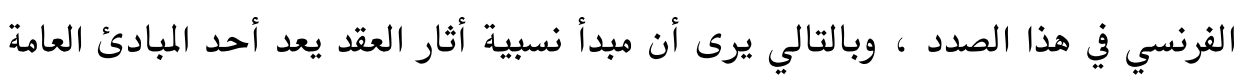

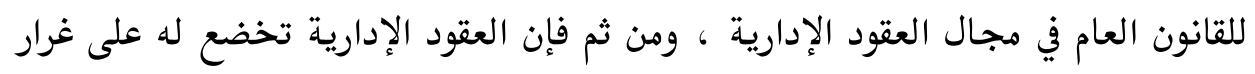

العقود المدنية (1)

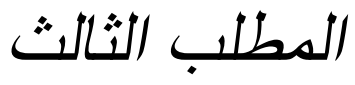

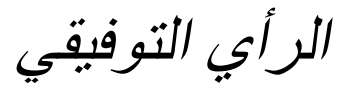

هناك اتجاه ثالث اعتمد موقفاً توفيقياً ، على خلاف الرأي الأول الرافض لخضوع

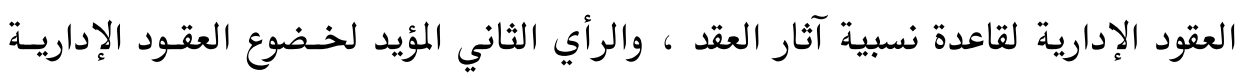

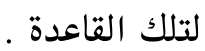
هذا الرأي تزعمه الدكتور إبراهيم طه الفياض(") حيث يرى أن القاعدة العامـة هـو

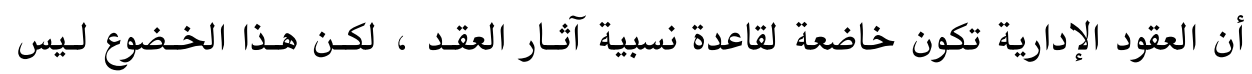

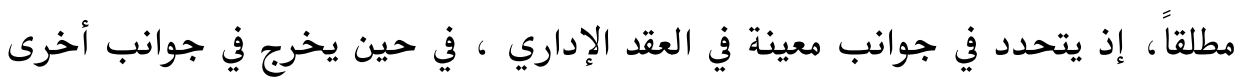

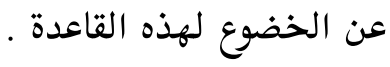

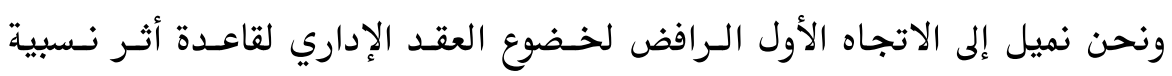

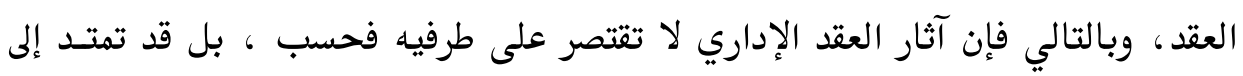

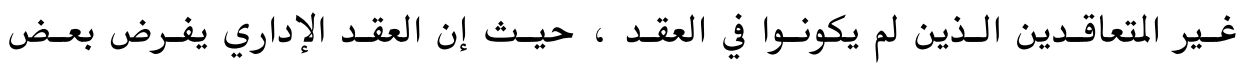

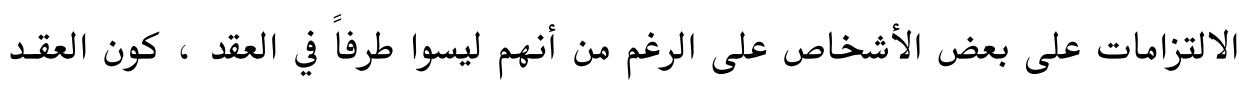

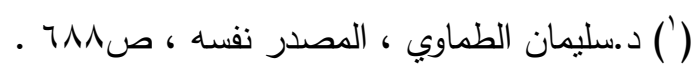

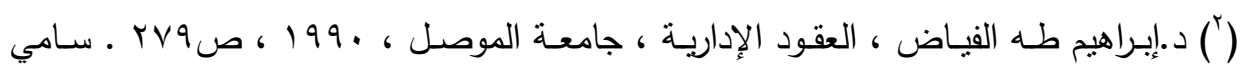

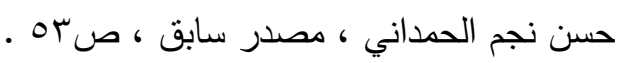


الإداري يتصل بخدمة مرفق عام والمتعاقد مع الإدارة يسساهم بـدون شـك في تسيير هـذا المرفق ، والإدارة قد ترى منح المتعاقد ولاسيما ملتزم المرفق العام بعسض السسلطات الـتي تخوله فرض بعض الأعباء على الأفراد بالرغم من أنهم يعتبرون من الغير بالنسبة للعقد

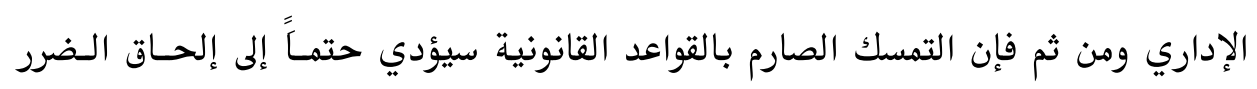
بالغير ، وهذا في الواقع ينسجم مع المنطق القانوني المجرد كون إبطال التصرفات الـتي

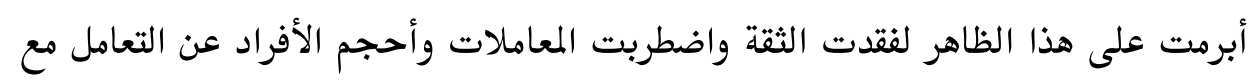
الإدارة مستقبلاً .

\section{الخاتمة :}

مسن خلال البحث في موضوع قاعدة نسبية أثـر العقـد وهـدى سـريانه على العقـد الإداري / دراسة مقارنة . اتضحت أهم الاستنتاجات والتوصيات كما يأتي :

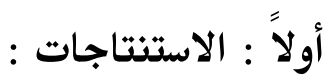

ا. اتضح لنا من خلال الدراسة ، أنه بخصوص خضوع كل مسن العقد الإداري المـدني والعقد الإداري إلى قاعدة نسبية أثر العقد ، تبين أن العقد الإداري يتميز عن العقـد

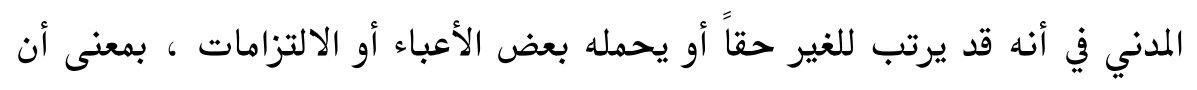
آثار العقد الإداري لا تقتصر على طرفيه فقط ، بل تمتد في بعض الحالات إلى الغير

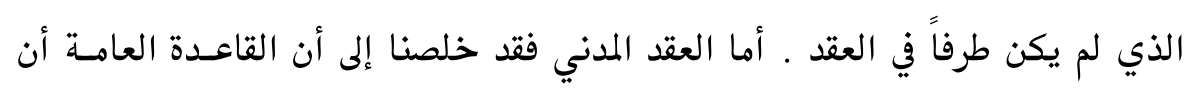
أثاره تقتصر علسى طرفيسه ولا يمتـد إلى الغـير ، واسـتثناءً مسن هـذه القاعـدة العامسة

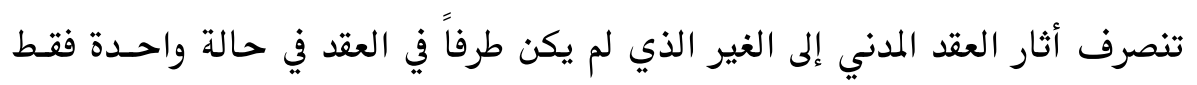
وهي حالة الاشتراط لمصلحة الغير . 


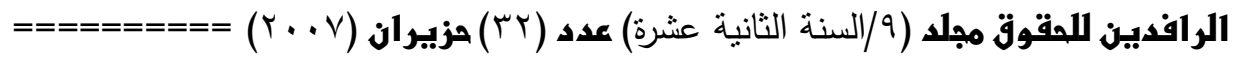

r. ت تبين لنا أن معنى الغير لا يثير أي صعوبة فيما يخص الأشـخاص الدذين يتعـاملون

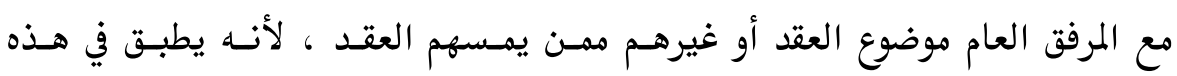

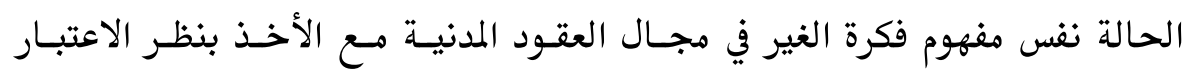
الأحكام الخاصة بالخلف العام والخلف الخاص ـ إلا أن الصعوبة يمكن أن تثأر في تحديد معنى الغير بالنسبة للجهات الإدارية التي تعد من قبيـل الغير تجـاه عقد

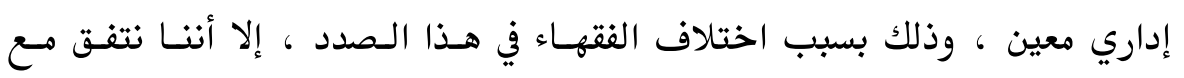

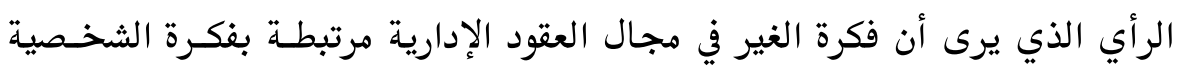

$$
\text { ثانياً : التوصيات : المعنوية . }
$$

إن القوانين الإدارية ولاسيما في مجال العقود الإدارية لم تتطرق إلى إيـراد نـصوص

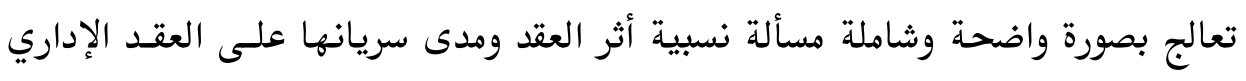

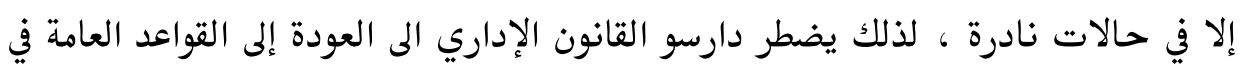

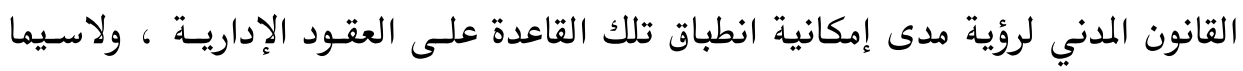

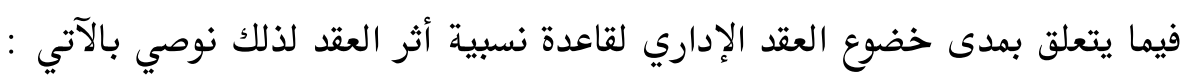

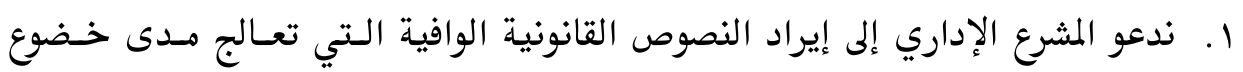

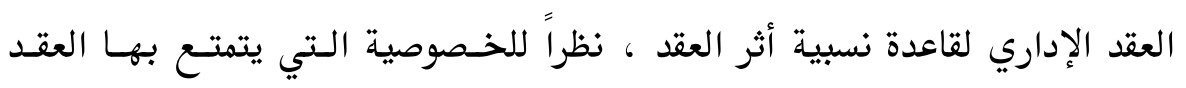

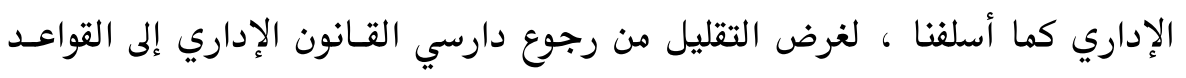

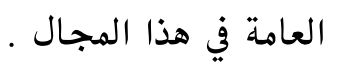
r. . ضرورة دعم فكرة أن العقود الإدارية لا تخضع لقاعـدة نسبية أثر العقد المقررة في

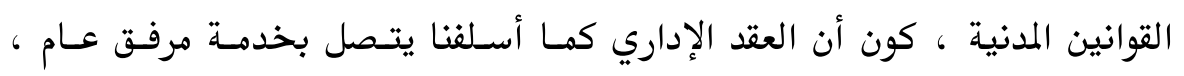


(اعله

والمتعاقد مع الإدارة يساهم بـدون شـك في تسيير هـذا المرفـق ، فـضلاً عـن النظــام القانوني الذي يخضع له العقد الإداري المختلف تماماً عن العقد المدني . 


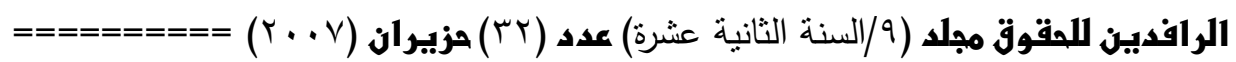

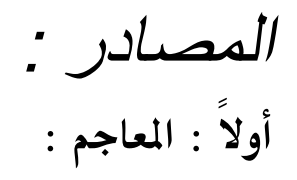

1. أبن منظور جمال الدين محمد بن مكرم ، لسان العرب ، الجـزء السادس ، الـدار

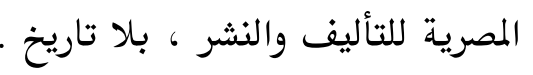
ثانياً : الكتب القانونية والعامة : 1. إ. د.إراهيم طه الفياض ، القانون الإداري ، ط بلا ، مكتبة الفلاح ، الكويت . r r. ب. د.إبراهيم طه الفياض ، العقود الإدارية ، جامعة الموصل .

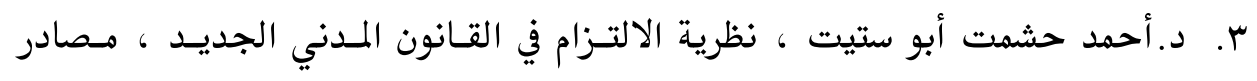

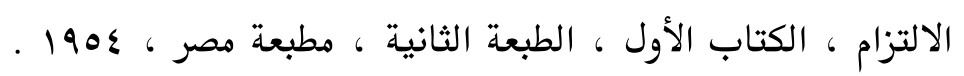

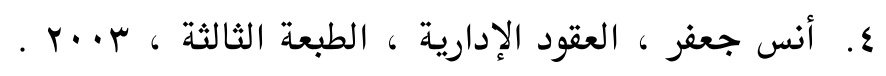

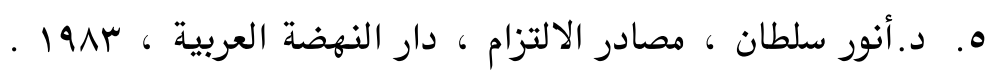

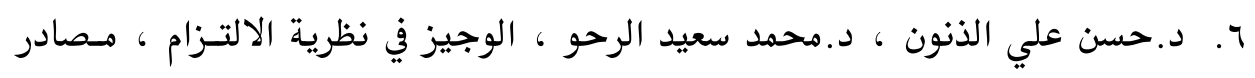

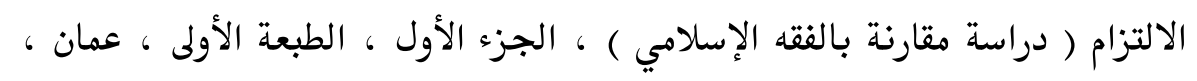

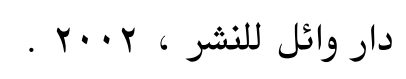

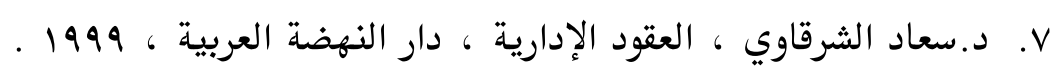

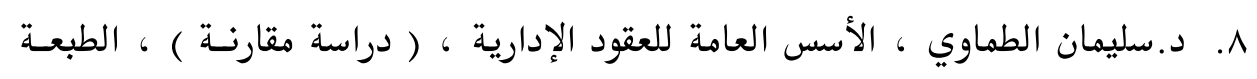
الرابعة ، مطبعة جامعة عين شمس ، ع191 .

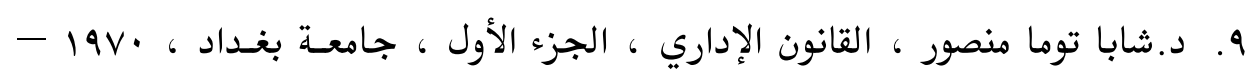
.1971 
• ا. . د.عاصم أحمد عجيلة ، د.محمد رفعت عبد الوهاب ، القانون الإداري الـيمني ، الطبعة الثالثة ، جامعة صنعاء ، $19 \wedge 1$.

ال. د.عبد الرزاق السنهوري ، الوجيز في شرح القانون المدني ، دار النهضة العربيـة ، .1977

ץ ا. ـ د.عبد الرزاق السنهوري ، الوسيط في شرح القانون المدني ، الجزء الأول ، المجلـد الأول ، العقد ، دار النهضة العربية ، 1911 .

با . د.عبد العليم عبد المجيد مشرف ، حدود انصراف أثـر العقـد الإداري إلى الغسير ،

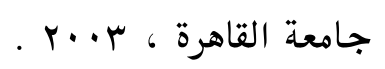

ع ـ ـ د.عبد القادر الفار ، مصادر الالتزام ، (مصادر الحق الشخصي في القانون المدني) ، مكتبة دار الثقافة للنشر والتوزيع ، عمان 1991 ـ

ه . . د.عبد المجيد الحكيم ، عبد الباقي البكري ، محمد طه البشير ن الوجيز في نظرية الالتزام في القانون المدني العراقي ، الجزء الأول ، ·191 .

جا. . عمر حلمي وآخرون ، المبادئ العامة في العقـود الإداريسة ، دار النهـضة العربيسة ، $.199 V$

IV . د.فكري أحمسد سـنجر ، المرافتق العامسة الكـبرى ، المطبعـة الإقليميسة بمـراكش ، $.19 \wedge \varepsilon$

1 ا . د.ماهر صالح علاوي ، مبادئ القانون الإداري ، ( دراسة مقارنة ) ، جامعة بغداد .1997.

19 ـ د.محمد منير الوتري ، العقود الإدارية وأنماطها التطبيقية ، الجزء الأول ، مطبعـة

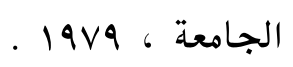




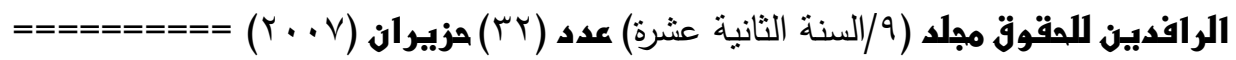

• ·. د.محمود جمال الدين زكي ، الذظرية العامة للالتزام ، دار النشر وسنة النشر غـير مذكورتين .

اب. . د.نواف الكنعان ، القانون الإداري ( الكتاب الثاني ) ، كلية الحقـوق ، الجامعـة

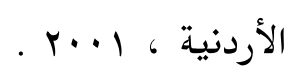

ثالثاً : الرسائل والأطاريح الجامعية : لردئ

ا ـ سامي حسن نجم الحمداني ، أثر العقد الإداري بالنسبة إلى الغير ، رسالة ماجستير

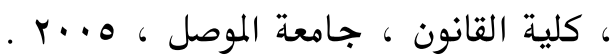

رابعاً : القوانين :

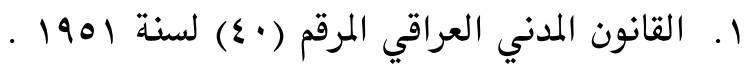

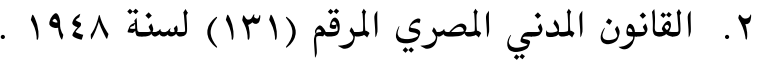

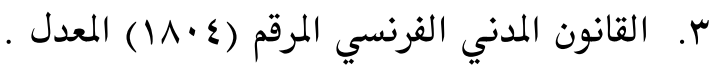

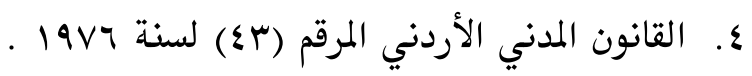

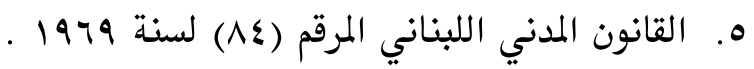

خامساً : الموسوعات والقرارات القضائية :

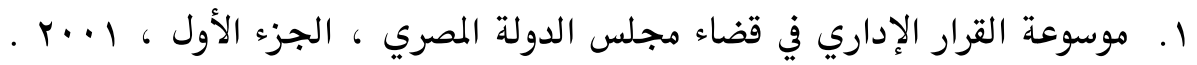
r. مجموعة المبادئ القانونية التي قرتها المحكمة الإداريسة العليـا المـصرية ، المكتـب

سادساً : المصادر الفرنسية :

1 - Louis Rolland, pieces droit administratif, 1926.

2- Marcel Hourio, précis de droit administratif et de droit puplic , 1933. 